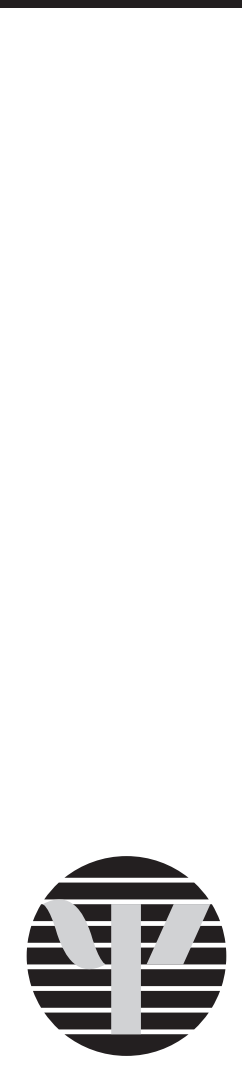

AMERICAN

PSYCHOLOGICAL ASSOCIATION

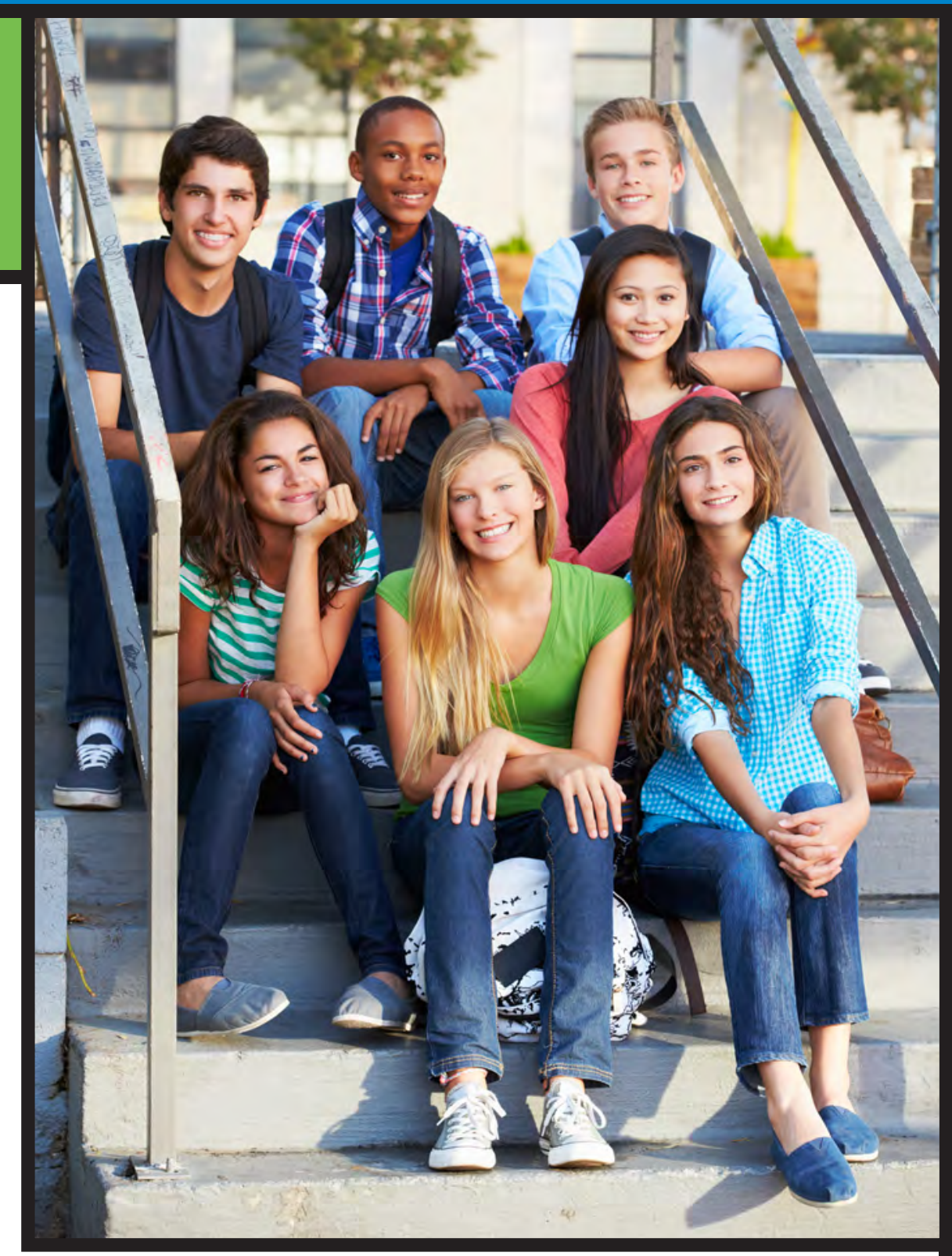

TOP 20 PRINCIPLES FROM PSYCHOLOGY FOR PREK-12

CREATIVE, TALENTED, AND GIFTED STUDENTS' TEACHING AND LEARNING

Center for Psychology in Schools and Education 


\section{TOP 20 PRINCIPLES FROM PSYCHOLOGY FOR PREK-12 CREATIVE, TALENTED, AND GIFTED STUDENTS' TEACHING AND LEARNING}

\section{CENTER FOR PSYCHOLOGY IN SCHOOLS AND EDUCATION}

\section{Contributors}

Linda Brody, EdD

Elissa Brown, PhD

Lannie Kanevsky, $\mathrm{PhD}$

Tonya Moon, $\mathrm{PhD}$

Pamela Clinkenbeard, PhD Maureen Neihart, PsyD

J ennifer Cross, $\mathrm{PhD}$

Tracy Cross, $\mathrm{PhD}$

Marta Fulop, $\mathrm{PhD}$

Scott Hunsaker, $\mathrm{PhD}$

Susan J ohnsen, $\mathrm{PhD}$

Mojca J urisevic, $\mathrm{PhD}$

Layne Kalbfleisch, PhD

\section{Reviewers}

Katie de St. Paer, MA

Rima Binder, $\mathrm{PhD}$

J eb Puryear, $\mathrm{PhD}$

Michelle Swain, MEd

Matthew Zakreski, PsyD

\author{
Editors and Co-Chairs \\ Matthew Makel, $\mathrm{PhD}$ \\ Paula Olszewski- \\ Kubilius, $\mathrm{PhD}$ \\ J onathan Plucker, $\mathrm{PhD}$ \\ Rena Subotnik, $\mathrm{PhD}$
}

\section{COALITION FOR PSYCHOLOGY IN SCHOOLS AND EDUCATION Contributing Authors \\ J oan Lucariello, $\mathrm{PhD}$ (Chair) \\ Russ Skiba, $\mathrm{PhD}$ \\ Sandra Graham, $\mathrm{PhD}$ \\ Bonnie Nastasi, $\mathrm{PhD}$ \\ Carol Dwyer, $\mathrm{PhD}$ \\ J onathan Plucker, PhD \\ Mary Pitoniak, $\mathrm{PhD}$ \\ Mary Brabeck, $\mathrm{PhD}$ \\ Darlene DeMarie, $\mathrm{PhD}$ \\ Steve Pritzker, $\mathrm{PhD}$}

APA Staff Liaisons

Rena F. Subotnik, $\mathrm{PhD}$

G. Maie Lee, MA

Thanks to the following members and former members of the coalition and supporters for their contributions as reviewers:

Larry Alferink, $\mathrm{PhD}$

Eric Anderman, $\mathrm{PhD}$

J oshua Aronson, $\mathrm{PhD}$

Cynthia Belar, PhD

Hardin Coleman, $\mathrm{PhD}$

J ane Conoley, $\mathrm{PhD}$

Tim Curby, PhD

\author{
Robyn Hess, $\mathrm{PhD}$ \\ Randy Kamphaus, $\mathrm{PhD}$ \\ J ames Mahalik, $\mathrm{PhD}$ \\ Rob McEntarffer, PhD \\ J ohn Murray, $\mathrm{PhD}$ \\ Sam Ortiz, PhD \\ Isaac Prilleltensky, $\mathrm{PhD}$
}

\author{
Yadira Sanchez, PsyD \\ Peter Sheras, $\mathrm{PhD}$ \\ Gary Stoner, $\mathrm{PhD}$ \\ Adam Winsler, $\mathrm{PhD}$ \\ J ason Young, $\mathrm{PhD}$
}

A copy of this report is available online at http:/ / www.apa.org/ ed/ schools/ teaching-learning/top-twenty-principles.aspx

Suggested bibliographic reference:

American Psychological Association, Center for Psychology in Schools and Education. (2017). Top 20 principles from psychology for preK- 12 creative, talented, and gifted students' teaching and learning. Retrieved from http:// www.apa.org/ ed/schools/ teaching-learning/top-twenty-principles.aspx
Copyright @ 92017 by the American Psychological Association. This material may be reproduced and distributed without permission provided that acknowledgment is given to the American Psychological Association. This material may not be reprinted or translated without prior permission in writing from the publisher. For permission, contact APA, Rights and Permissions, 750 First Street, NE, Washington, DC 20002-4242.

APA reports synthesize current psychological knowledge in a given area and may offer recommendations for future action. They do not constitute APA policy or commit APA to the activities described therein. This particular report originated with the Coalition for Psychology in Schools and Education, an APA-sponsored group of psychologists representing APA divisions and affiliated groups. 


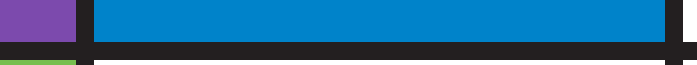




\section{CONTENTS}

Top 20 Principles From Psychology for PreK- 12 Creative, Talented, and Gifted Students' Teaching and Learning .................................. 1

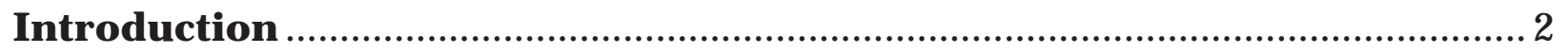

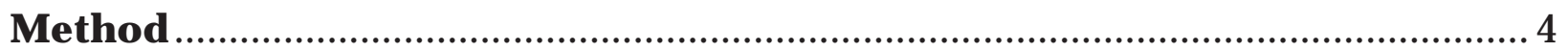

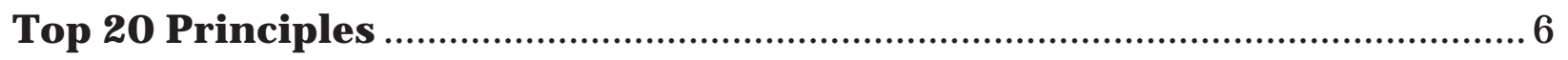

How Do Students Think and Learn? Principles 1- 8 ....................................... 6

What Motivates Students? Principles 9- 12 ........................................................ 21

Why Are Social Context, Interpersonal Relationships, and Emotional Well-Being Important to Student Learning? Principles 13- 15 ....................... 29

How Can the Classroom Best Be Managed? Principles 16- 17.......................... 36

How to Assess Student Progress? Principles 18-20 …........................................ 39 

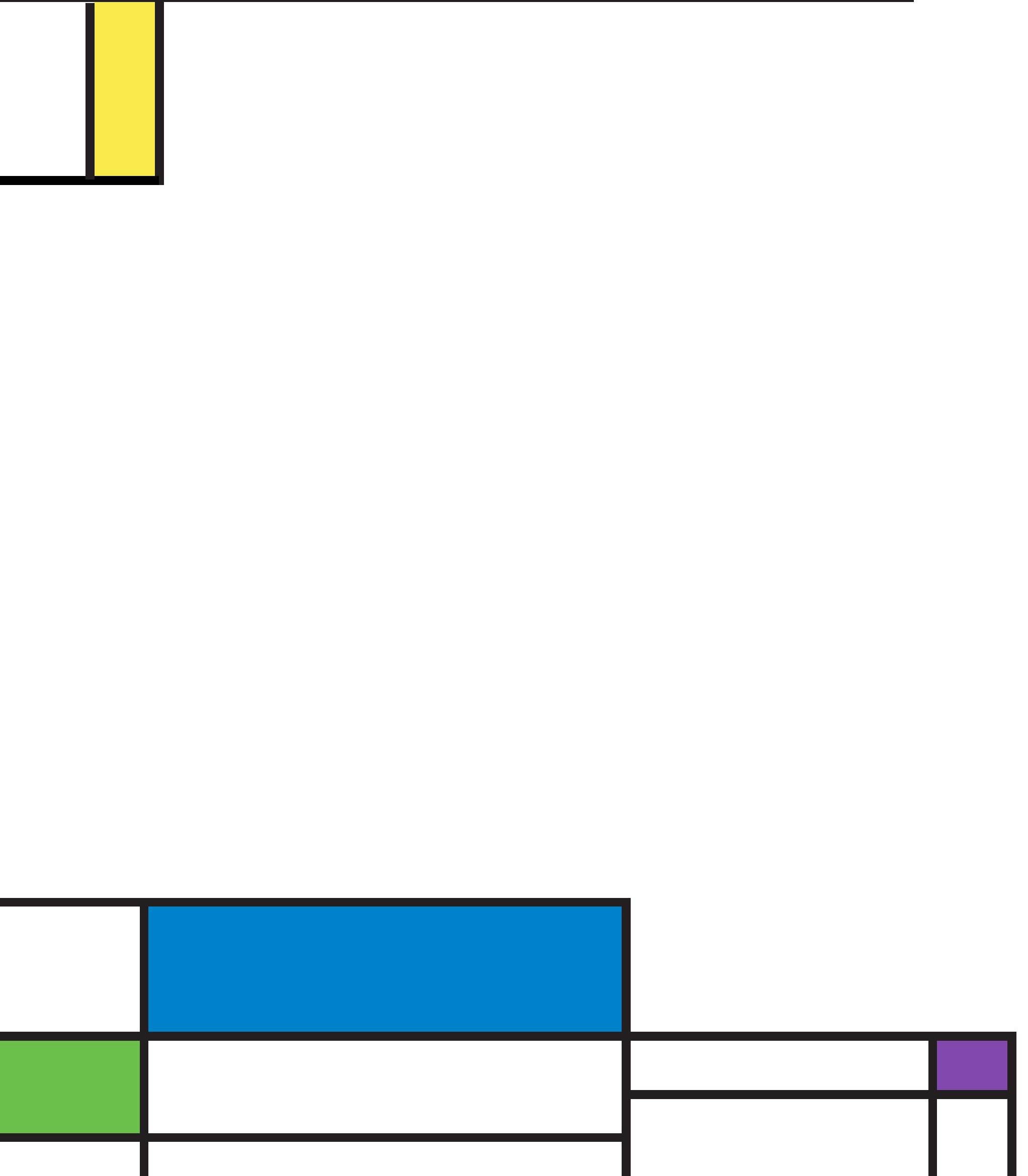
PRINCIPLE 1 Students' beliefs or perceptions about intelligence and ability affect their cognitive functioning and learning.

PRINCIPLE 2 What students already know affects their learning.

PRINCIPLE 3 Students' cognitive development and learning are not limited by general stages of development.

PRINCIPLE 4 Learning is based on context, so generalizing learning to new contexts is not spontaneous but instead needs to be facilitated.

PRINCIPLE 5 Acquiring long-term knowledge and skill is largely dependent on practice.

PRINCIPLE 6 Clear, explanatory, and timely feedback to students is important for learning.

PRINCIPLE 7 Students' self-regulation assists learning, and self-regulatory skills can be taught.

PRINCIPLE 8 Student creativity can be fostered.

PRINCIPLE 9 Students tend to enjoy learning and to do better when they are more intrinsically rather than extrinsically motivated to achieve.

PRINCIPLE 10 Students persist in the face of challenging tasks and process information more deeply when they adopt mastery goals rather than performance goals.

PRINCIPLE 11 Teachers' expectations about their students affect students' opportunities to learn, their motivation, and their learning outcomes.
PRINCIPLE 12 Setting goals that are short-term (proximal), specific, and moderately challenging enhances motivation more than establishing goals that are long-term (distal), general, and overly challenging.

PRINCIPLE 13 Learning is situated within multiple social contexts.

PRINCIPLE 14 Interpersonal relationships and interpersonal communication are critical to both the teaching-learning process and the social development of students.

PRINCIPLE 15 Emotional well-being influences educational performance, learning, and development.

PRINCIPLE 16 Expectations for classroom conduct and social interaction are learned and can be taught using proven principles of behavior and effective classroom instruction.

PRINCIPLE 17 Effective classroom management is based on (a) setting and communicating high expectations, (b) consistently nurturing positive relationships, and (c) providing a high level of student support.

PRINCIPLE 18 Formative and summative assessments are both important and useful but require different approaches and interpretations.

PRINCIPLE 19 Students' skills, knowledge, and abilities are best measured with assessment processes grounded in psychological science with well-defined standards for quality and fairness.

PRINCIPLE 20 Making sense of assessment data depends on clear, appropriate, and fair interpretation. 


\section{INTRODUCTION}

Psychological science has much to contribute to enhancing teaching and learning in both regular education and gifted education classrooms. Teaching and learning are intricately linked to social and behavioral factors of human development, including cognition, motivation, social interaction, and communication. Psychological science can also provide key insights on effective instruction, classroom environments that promote learning, and appropriate use of assessment, including data, tests, and measurement, as well as research methods that inform the practice of serving gifted students. We present here a gifted education supplement to a list of the most important principles from psychology - the "Top 20"-that would be of greatest use in the context of preK- 12 classroom teaching and learning, as well as the implications of each principle as applied to classroom practices for gifted students. Each principle is named and described, relevant supporting literature is provided, and its relevance for the gifted classroom is discussed.

The work of identifying and translating psychological principles for use by preK- 12 practitioners was originally conducted by a coalition of psychologists, known as the Coalition for Psychology in Schools and Education, which is supported by the American Psychological Association (APA). The current version expanded the document to add information for the gifted education context. The coalition was an ideal group for translating psychological science for classroom use because its members collectively represent a wide spectrum of subdisciplines in psychology, including evaluation, measurement, and statistics; developmental psychology; personality and social psychology; the psychology of aesthetics, creativity, and the arts; consulting psychology; educational psychology; school psychology; counseling psychology; community psychology; psychology of women; media psychology and technology; group psychology and group psychotherapy; psychological study of men and masculinity; and clinical child and adolescent psychology.

Also involved in the coalition were psychologists representing communities of educators and scientists, as well as specialists in ethnic minority affairs; testing and assessment; teachers of psychology in secondary schools; children, youth, and families; and psychology honor societies. Coalition members are employed in
$\mathrm{K}-12$ schools and in colleges and universities in education, liberal arts, and science divisions. Some members are in independent practice. All hold expertise in psychology's application to early childhood, elementary, secondary, or special education.

The coalition specifically, and APA generally, has been putting psychological science to work for preK- 12 education for over a decade. There are many modules and white papers for teachers on the APA website (http:// www.apa.org/ed/schools/index.aspx). The Top 20 project was modeled after APA's earlier effort to identify Learner-Centered Psychological Principles (1997). This initiative updates and broadens those principles.

We present here the most important principles from psychology as identified by the Coalition for Psychology in Schools and Education-the Top 20-that would be of greatest use in the context of preK- 12 classroom teaching and learning with gifted children and youth. The field of gifted education has not come to any resolution about universal definitions of giftedness, talent, and creativity and how they should be measured. This made our task much more difficult. Which students are considered gifted, talented, or creative varies based on local or state policy. Different schools use different identification criteria and cutoffs. Moreover, some schools identify students on the basis of specific do- 
mains (e.g., math, language arts), whereas others identify more holistically. Such identification differences can play a distinct role in which advice and types of services are appropriate. For ease of readership, we use the term gifted throughout the document to stand more generally for gifted, talented, and creative. Given the lack of consensus on definitions, the scholars participating in this project relied to the best of their ability on the most rigorous research available. Most important, gifted children, like all children, are best taught when the Top 20 principles included in this document are in place and supported by the administration and faculty.
We encourage consideration and practice of the Top 20 throughout all teacher preparation programs and gifted education licensure to ensure a solid foundation of psychological knowledge in preK- 12 instruction of gifted students.

Note: A short reference section is included at the end of each principle. A "+” appears before each reference that was added specifically for this gifted education supplement. 


\section{METHOD}

\section{The method to derive the Top 20 principles was as follows. The coalition, operating in the mode of a National Institutes of Health consensus panel, engaged in a series of activities. First, each member was asked to identify two constructs or "kernels" (Embry \& Biglan, 2008) from psychology thought to be most essential for facilitating successful classroom teaching and learning. This process led to the identification of approximately 45 kernels/ principles.}

Next, steps were taken to categorize, validate, and consolidate these principles. The first step was to cluster the 45 principles according to key domains of classroom application (e.g., How do students think and learn?). This was conducted in an iterative process across several meetings of the coalition.

Second, a validation procedure for the 45 principles was undertaken. Several national blueprint publications related to teaching were analyzed to assess whether each of these principles also had been identified by the broader community of educators as critical to teacher practice. Cross-checking analyses were conducted on APA's standards for high school curriculum in psychology; the PRAXIS Principles of Learning and Teaching examination from the Educational Testing Service; documents from the National Council for the Accreditation of Teacher Education; the InTASC (the Interstate Teacher Assessment and Support Consortium) standards; a popular educational psychology textbook; and the National Association of School Psychologists' Blueprint for Training and Practice. These documents were searched for evidence of what teachers were expected to know or be able to do and whether these expectations could be linked to the principles that the coalition had identified. There was support for all principles in one or more docu- ments. Hence, all were retained for the next step in the validation process.

To identify the most important of the 45 principles/ kernels, the coalition used a modified Delphi process (modeled after the Institute of Medicine's report Improving Medical Education: Enhancing the Behavioral and Social Science Content of Medical School Curricula). Using a scale system, four coalition members rated each of the principles and assigned each a high, medium, or low priority score (1-3). Mean scores for each item were calculated. On the basis of the mean scores, low-priority principles were discarded, leaving 22 principles. These were then analyzed for their relation to each other and were synthesized into the final 20 presented here.

These Top 20 were then placed into five areas of psychological functioning. The first eight principles relate to cognition and learning and address the question How do students think and learn? The next four (9-12) discuss the question What motivates students? The following three (13-15) pertain to the social context and emotional dimensions that affect learning and focus on the question Why are social context, interpersonal relationships, and emotional well-being important to student 
learning? The next two principles (16- 17) relate to how context can affect learning and address the question How can the classroom best be managed? Finally, the last three principles (18-20) examine the question How can teachers can assess student progress?

The gifted education community was informally surveyed to see if it might be useful to have a supplemental version that addressed the 20 principles with respect to gifted students. The response was very positive. Thus, a panel of gifted education experts with expertise relevant to each of the principles was established to update and expand each principle to incorporate relevant evidence on gifted education practices.

\section{REFERENCES}

American Psychological Association, Learner-Centered Principles Work Group. (1997). Learner-centered psychological principles: A framework for school reform and design. Retrieved from http:// www.apa.org/ ed/ governance/ bea/ learner-centered.pdf

Benassi, V. A., Overson, C. E., \& Hakala, C. M. (Eds.). (2014). Applying the science of learning in education: Infusing psychological science into the curriculum. Retrieved from the Society for the Teaching of Psychology website: http:// teachpsych.org/ resources/documents/ ebooks/ asle2014.pdf

Council of Chief State School Officer's Interstate Teacher Assessment and Support Consortium (InTASC). (2011). Model core teaching standards: A resource for state dialogue. Retrieved from http:// www.ccsso.org/ Documents/2011/InTASC_Model_Core_Teaching_Standards_2011.pdf

Cuff, P. A., \& Vanselow, N. A. (Eds.). (2004). Enhancing the behavioral and social sciences in medical school curricula. Washington DC: National Academies Press.

Dunlosky, J ., Rawson, K. A., Marsh, E. J ., Nathan, M. J ., \& Willingham, D. T. (2013). Improving students' learning with effective learning techniques: Promising directions from cognitive and educational psychology. Psychological Science in the Public Interest, 14, 4- 58. doi:10.1177/ 1529100612453266

Educational Testing Service. (2015). Principles of learning and teaching. Retrieved from https:// www.ets.org/ praxis/ prepare/ materials/ 5622

Embry, D. D., \& Biglan, A. (2008). Evidence-based kernels: Fundamental units of behavioral influence. Clinical Child and Family Psychology Review, 11(3), 75- 113. doi:10.1007/ s10567-0080036-x

Institute of Medicine. (2004). Improving medical education: Enhancing the behavioral and social science content of medical school curricula. Retrieved from http:// www.ncbi.nlm.nih.gov/ pubmed/ 20669422

Roediger, H. L. (2013). Applying cognitive psychology to education: Translational education science. Psychological Science in the Public Interest, 14, 1- 3. doi:10.1177/ 1529100612454415
Whitlock, K. H., Fineburg, A. C., Freeman, J . E., \& Smith, M. T. (2005). National standards for high school psychology curricula. Retrieved from the APA website: http:// www.apa.org/ about/ policy/ high-school-standards.pdf

Woolfolk, A. (2013). Educational psychology (12th ed.). Upper Saddle River, NJ : Pearson.

Ysseldyke, J ., Burns, M., Dawson, P., Kelley, B., Morrison, D., Ortiz, S., ... Telzrow, C. (2006). School psychology: A blueprint for training and practice III. Retrieved from the National Association of School Psychologists' website: http:// www.naspcenter. org/ blueprint

Zinkiewicz, L., Hammond, N., \& Trapp, A. (2003). Applying psychology disciplinary knowledge to psychology teaching and learning: A review of selected psychological research and theory with implications for teaching practice. York, UK: University of York. 


\section{How do students think and learn?}

\section{PRINCIPLE 1 Students' beliefs} or perceptions about intelligence and ability affect their cognitive functioning and learning.

\section{EXPLANATION}

Students who believe intelligence is malleable and not fixed are more likely to adhere to an "incremental" or "growth" mindset about intelligence. Those who hold the opposite view, that intelligence is a fixed trait, tend to adhere to the "entity" theory of intelligence. Students holding to the latter view focus on performance goals and believe they continually need to demonstrate and prove their intelligence, making them more hesitant to take on highly challenging tasks and more vulnerable to negative feedback than students holding an incremental view. Students with an incremental mindset generally focus on learning goals and are more willing to engage in challenging tasks in an effort to test and expand (as opposed to prove) their intelligence or ability. Hence, they rebound more easily from negative feedback and failure. Accordingly, students who believe that intelligence and ability can be enhanced tend to perform better on a variety of cognitive tasks and in problem-solving situations.

In keeping with this principle, research has shown that gifted students are more likely to attribute failure to not working hard enough rather than to their lack of ability. When they do experience success, it is because they are generally more able to self-regulate, access cognitive-learning strategies, and apply what they have previously learned to new tasks, problems, and processes. In one sample, gifted children who had a high degree of creative self-efficacy (i.e., a belief in their own ability to be creative) were more likely to hold positive beliefs and mindsets about their general ability and consequently engage in different types of learning situations in and outside of school. Some research indicates that gifted children see a relationship between intelligence and giftedness but attribute the meaning of these terms to two different mindsets; students were more likely to view intelligence as malleable and giftedness as a "fixed" trait.

One evidence-based approach to fostering a growth mindset is framed in terms of the attributions that teachers assign to student performances. When students experience failure, they are likely to ask why. The answer to that "why" question is a causal attribution. Students cope better when they attribute failure to lack of effort rather than to low ability because the former is unstable (effort fluctuates over time) and controllable (students can generally try harder if they want to). Attributing failure to lack of effort or other unstable and controllable causes, such as poor choice of strategy, allows the student to maintain hope that things can be different in the future and performance improved.

Gifted students are likely, but not always, to attribute failure to a lack of effort rather than question their ability. When students believe their performance can be improved, they are acquiring a growth mindset that can bring to bear motivation and persistence when they encounter challenging problems or material. In cases of underachievement, gifted children experience difficulties with motivation and task commitment. In these cases, if a teacher can determine how a student interprets his or her ability (fixed or incremental), the teacher can support or reestablish a positive mindset by differentiating processes to influence motivation and task commitment.

\section{RELEVANCE FOR TEACHERS}

Teachers can foster students' beliefs that their intelligence and ability can be developed through effort and experiences that foster higher motivation, aspirations, and achievement. There are a variety of ways in which teachers can support such student beliefs in a growth mindset. 
For gifted students, giving them a sense of control over their learning process by using such strategies as problem-based and discovery learning and independent study can promote several kinds of learning outcomes simultaneously-collaboration, problem solving, and flexible thinking.

- When a task is easy (gifted students encounter this frequently), it is especially important for teachers to avoid generating ability-based attributions. When teachers praise a student by saying "You're so smart" after the student has finished a task or quickly figured out an answer to a relatively unchallenging problem, the teacher may inadvertently encourage that student to associate smartness with speed and lack of effort. Gifted students often have a strong capacity for recall, so these associations can become problematic when students are later presented with more challenging material or tasks that require more time, effort, and/or the use of different approaches.

- When presenting students with challenging materials and tasks, teachers may want to be aware of situations in which students expend minimal, modest, or incomplete effort. This self-handicapping may reflect a student's fear of embarrassment or failure ("If I don't even try, people will not think I'm dumb if I fail"). This dynamic comes into play with gifted children who have perfectionistic tendencies, meaning they are likely to take risks in situations in which they are sure they can excel. It is important to reward reflective thinking as much as speed of recall. Gifted students who are underachieving may display tendencies of learned helplessness or may, in the case of "twice-exceptional" students (gifted students with learning, developmental, behavioral, or emotional disability), have deficits that suggest they will not engage in a task when they may actually lack some of the key skills necessary to complete a task. In those cases, helping students find good ways to "scaffold" so they can learn a new skill or compensate for a weakness can help them overcome insecurity related to intellectual risk taking.

- Because young gifted children may have a tendency to expect everything will be easy to learn and/ or do based on early mastery and academic success, maintaining consistent responses to success and to failure will support constructive risk taking as content and skills become more challenging.

- Research has shown that when teachers are consistent in their offer of help to all students and communicate mild and constructive criticism following failure, students are more likely to attribute their failure to lack of effort and to believe their teachers have high expectations that they will do better in the future.

For the best impact, instead of giving compliments and sympathy, focus on improving behavior by modeling and offering constructive criticism to better highlight what students are doing well and where they can improve. Attribution principles, which are intricately linked to mindset, help explain how some well-intentioned teacher behaviors may have unexpected, or even negative, effects on students' beliefs about their own abilities. For gifted students, it is important to determine when a student needs good critical feedback, modeling, practice, introspection, or freedom to elaborate on a point of interest.

\section{REFERENCES}

Aronson, J., Fried, C. \& Good, C. (2002). Reducing the effects of stereotype threat on African American college students by shaping theories of intelligence. J ournal of Experimental Social Psychology, 38, 113-125. doi:10.1006/jesp.2001.1491

Aronson, J ., \&J uarez, L. (2012). Growth mindsets in the laboratory and the real world. In R. F. Subotnik, A. Robinson, C. M. Callahan, \& E. J . Gubbins (Eds.), Malleable minds: Translating insights from psychology and neuroscience to gifted education (pp. 19- 36). Washington, DC: Department of Education.

+Assouline, S. G., Colangelo, N., Ihrig, D., \& Forstadt, L. (2006). Attributional choices for academic success and failure by intellectually gifted students. Gifted Child Quarterly, 50, 283- 294.

+Beghetto, R. A. (2006). Creative self-efficacy: Correlates in middle and secondary students. Creativity Research J ournal, 18, 447-457.

Blackwell, L. S., Trzesniewski, K. H., \&Dweck, C. S. (2007). Implicit theories of intelligence predict achievement across an adolescent transition: A longitudinal study and an intervention. Child Development, 78, 246-263. doi:10.1111/j.1467-8624.2007.00995.x

+Clinkenbeard, P. R., (2012). Motivation and gifted students: Implications of theory and research. Psychology in Schools, 49, 622- 630 .

Dweck, C. S. (2006). Mindset: The new psychology of success. New York, NY: Random House.

Good, C., Aronson, \&J . Inzlicht, M. (2003). Improving adolescents' standardized test performance: An intervention to 
reduce the effects of stereotype threat. J ournal of Applied Developmental Psychology, 24, 645-662. doi.org/ 10.1016/j. appdev.2003.09.002

+Lauermann, F., Chow, A., \& Eccles, J. S. (2015). Differential effects of adolescents' expectancy and value beliefs about math and English on math/ science-related and human-services-related career plans. International J ournal of Gender, Science and Technology, 7(2), 205- 228.

+Makel, M. C., Snyder, K. E., Thomas, C., Malone, P. S., \& Putallaz, M. (2015). Gifted students' implicit beliefs about intelligence and giftedness. Gifted Child Quarterly, 59, 203- 212.

+Neber, H., \& Schommer-Aikins, M. (2002). Self-regulated science learning with highly gifted students: The role of cognitive, motivational, epistemological, and environmental variables. High Ability Studies, 13(1), 59- 74.

\section{PRINCIPLE 2 What students already know affects their learning.}

\section{EXPLANATION}

Students come to classrooms with knowledge based on their everyday experiences, social interactions, intuitions, and what they have been taught in other settings and in the past. This prior knowledge affects how they will incorporate new learning because what students already know interacts with the material being learned. Accordingly, learning consists of either adding to existing student knowledge, known as conceptual growth, or transforming or revising student knowledge, known as conceptual change. Students' prior knowledge can help or hinder new learning, but what happens if students already know the course material, and repeated instruction does not increase the depth of their understanding? ${ }^{1}$ Empirical evidence indicates that "overlearning" does not increase the achievement of high-ability students. For example, a student who knows the purposes and functions of various parts of speech or a student who knows how to perform long division will not benefit from repeated instruction on these topics. In fact, being presented with content already understood and mastered results in negative student outcomes, such as disengagement, boredom, sloppy work, frustration, and negative attitudes toward school.

Some evidence suggests that gifted learners tend to have more elaborately organized knowledge bases, en-

${ }^{1}$ See http:// www.apa.org/ education/k12/ student-thinking.aspx code information more efficiently, have more information-processing strategies on hand, and can apply problem-solving strategies more quickly than others. These unique academic needs deserve to be addressed equitably in school; however, evidence suggests that this kind of modification occurs quite infrequently in general classrooms. Educational and psychological researchers have learned that optimal learning occurs when there is a match between the challenge level of the learning task and skill level of the learner, sometimes referred to as the zone of proximal development concept.

Teachers can gain an understanding of students' current level of mastery of course content by administering preassessments prior to instruction on a topic, using that information to document what students already know about a topic and eliminating instruction on already mastered material, and then providing appropriate and challenging instruction. This process is often referred to as curriculum compacting. Learning as conceptual growth occurs when student knowledge is consistent with material to be learned. Conceptual change is required when student knowledge is inconsistent or erroneous with respect to correct information. In these cases, students' knowledge consists of "misconceptions" or "alternative conceptions." Many common misconceptions are held by both students and adults, particularly in subjects such as mathematics and science. ${ }^{2}$

When the baseline assessment shows students to be harboring misconceptions, learning will require conceptual change - that is, revision or transformation of student knowledge. Achieving conceptual change in students is far more challenging for teachers than inducing conceptual growth because misconceptions tend to be entrenched in reasoning and resistant to change. Students, like anyone, can be reluctant to alter their thinking, because it is familiar to them. Also, students are generally unaware that their concepts are erroneous and hence believe them to be correct.

\section{RELEVANCE FOR TEACHERS}

Teachers are instrumental in assessing what gifted students already know and providing them with opportunities to learn new material, challenge misconceptions, and acquire new skills:

${ }^{2}$ See http:// www.apa.org/ education/k12/ misconceptions.aspx 
- To determine the academic readiness of students, teachers should administer preassessments, which can take a variety of formats, such as quizzes, performance tasks, production of concept maps, etc.

- Teachers should analyze preassessment information to determine what students already know and still need to know. They can also use this information to determine if students have misconceptions about material and if conceptual change is needed.

- Using preassessment information as well as information about students' interests and learning preferences, teachers can design new learning experiences for students that are challenging and appropriate for increasing students' conceptual growth.

- Teachers can be assured that increasing the pace for student learning, while providing careful monitoring, results in greater student achievement.

- Bringing about conceptual change requires teachers' use of specific instructional strategies. Many of these entail methods that precipitate cognitive conflict or dissonance in the minds of students by helping make them aware of the discrepancy between their own thinking and correct curricular material or concepts. For example: Teachers can have students play an active role in predicting solutions or processes and then show these predictions to be faulty. Teachers can also present students with credible information or data that run counter to their misconceptions.

\section{REFERENCES}

+Archambault, F. X., J r., Westberg, K. L., Brown, S. W., Hallmark, B. W., Zhang, W., \&Emmons, C. L. (1993). Classroom practices used with gifted third and fourth grade students. J ournal for the Education of the Gifted, 16,_103- 119.

+Csikszentmihalyi, M., \&Csikszentmihalyi, I. S. (Eds.). (1988). Optimal experience: Psychological studies of flow in consciousness. Cambridge, UK: Cambridge University Press.

Eryilmaz, A. (2002). Effects of conceptual assignments and conceptual change discussions on students' misconceptions and achievement regarding force and motion. J ournal of Research in Science Teaching, 39, 1001- 1015. doi.org/ 10.1002 / tea.10054

Holding, M., Denton, R., Kulesza, A., \& Ridgway, J . (2014). Confronting scientific misconceptions by fostering a classroom of scientists in the introductory biology lab. American Biology Teacher, 76, 518- 523.
Johnson, M., \& Sinatra, G. (2014). The influence of approach and avoidance goals on conceptual change. J ournal of Educational Research, 107, 312- 325. doi:10.1080/00220671.2013.807492

+Kanevsky, L., \& Geake, J . (2004). Inside the zone of proximal development: Validating a multifactor model of learning potential with gifted students and their peers. J ournal for the Education of the Gifted, 28, 182- 217.

Mayer, R. E. (2011). Applying the science of learning. Boston, MA: Pearson.

Pashler, H., Bain, P. M., Bottge, B. A., Graesser, A., Koedinger, K. R., McDaniel, M., \& Metcalfe, J . (2007). Organizing instruction and study to improve student learning (NCER 2007-2004). Washington, DC: U.S. Department of Education, Institute of Education Sciences, National Center for Education Research. Retrieved from http:/ / ies.ed.gov/ ncee/ wwc/ practiceguide.aspx?sid=1 +Reis, S. M., Westberg, K. L., Kulikowich, J ., Caillard, F., Hébert, T., Plucker, J ., . . Smist, J . (1993). Why not let high ability students start school in J anuary? The curriculum compacting study (Research Monograph 93106). Storrs, CT: University of Connecticut, National Research Center on the Gifted and Talented.

+Robinson, A., \& Clinkenbeard, P. R. (2010). History of giftedness: Perspectives from the past presage modern scholarship. In S. I. Pfeiffer (Ed.), Handbook of giftedness in children: Psychoeducational theory, research, and best practices (pp. 13- 32). New York, NY: Springer-Science +Business Media.

+Rorer, D., \& Taylor, K. (2006). The effects of overlearning and distributed practice on the retention of mathematics knowledge. Applied Cognitive Psychology, 20, 1209- 1124.

Savinainen, A., \& Scott, P. (2002). The Force Concept Inventory: A tool for monitoring student learning. Physics Education, 37, 45- 52 .

\section{PRINCIPLE 3 Students' cogni-} tive development and learning are not limited by general stages of development.

\section{EXPLANATION}

Student reasoning is not limited or determined by an underlying cognitive stage of development linked to an age or grade level. Instead, newer research on cognitive development has supplanted stage theory assumptions in favor of explanations that account for a greater range of individual differences in development, particularly within domains. In contrast to what stage theories would predict, infants and very young children have been found to have early, possibly biologically based, competencies in certain domains. 
For example, they can show knowledge of principles related to the physical world (e.g., that stationary objects are displaced when they come into contact with moving objects or inanimate objects need to be propelled into motion), biological causality (e.g., animate and inanimate entities differ), and numbers/numeracy (e.g., an understanding of numerical values up to three items). Studies of cognitive development and learning that emphasize the knowledge base of children reveal that students have many structures, known as schemas (i.e., mental representations), in place that guide their understanding when encountering new text and events.

Contextualist approaches to cognitive development and learning describe how context affects cognition. Supporters of these theories point out that cognition can be interpersonally and contextually based, such that reasoning can be facilitated to more advanced levels when students interact with more capable others and/ or with more advanced materials, particularly if learning is scaffolded with support. This strategy is especially effective when materials are pitched not too near or too far from their current level of functioning. This principle is captured in what is called the zone of proximal development. Contextualist approaches also support the idea that cognition can be "situated," whereby knowledge accrues through the lived practice of people in a society. That is, learning is conceived as participation in communities, with children progressively acquiring situated actions in real-world contexts (such as by farming or learning a craft or by participating in apprenticeships or internships).

Contextualist views of cognitive development are particularly relevant for understanding and promoting accelerated cognitive growth and learning among students with advanced academic abilities and/ or achievement (i.e., those who are performing or have the potential to perform at higher levels than their age or grade might typically predict). For these students, optimal cognitive and talent development depends on providing them with access to appropriately challenging content and to significant others who share their interests and abilities and can stimulate them intellectually. Research supports the efficacy of accelerative strategies and exposure to deep curricula in topic areas outside the regular curriculum to foster talent development among high-ability students, as well as the significant role that interaction with intellectual peers can play. It is important to note that cognitive abilities can be asynchronous (i.e., giftedness can be exhibited within a single domain and not carry over to the same extent to other domains or to noncognitive development). Individuals who vary in their abilities from domain to domain support the concept that it is not possible to place them within a single stage of cognitive development overall.

In sum, students are capable of higher level thinking and behavior when: (a) there is some biological base (early competency) for knowledge in the domain, (b) they already have some familiarity or expertise with a knowledge domain, (c) they are able to interact with more capable others and challenging materials, and (d) they are placed in sociocultural contexts with which they are familiar through experience. Conversely, when children are not familiar with a particular knowledge domain, not challenged by the interpersonal context or learning materials, or find the context of learning to be too unfamiliar, their reasoning may be less sophisticated and they may fail to achieve their full potential.

\section{RELEVANCE FOR TEACHERS}

Teachers should not assume that age or grade are the best determinants of what their students are capable of learning when making decisions about what material to present to them, particularly for students with advanced abilities or achievement levels. Instead, they should evaluate their students' domain-specific cognitive reasoning abilities, relevant content knowledge, and social and emotional needs and adjust content and the context in which it is presented accordingly. Teachers are encouraged to consider the following strategies to promote the learning and talent development of gifted students and to maximize the growth of their reasoning abilities:

- Use assessments to measure reasoning abilities and content knowledge before determining appropriate instructional levels. For students who perform near the ceiling on in-grade-level tests, use above-grade-level tests to assess the full extent of their knowledge and reasoning abilities. 
- Recognize that high ability and/ or advanced achievement can be domain specific, which means that identification of giftedness should be within specific domains and there should not be an expectation of exceptional performance in all areas to qualify for higher level differentiated instruction in areas of strength.

- Present content pitched at a moderate distance from students' current levels of functioning. New material should not repeat skills already mastered (thus pretesting is recommended) nor be too easily and quickly understood, but it should also not be so complex as to be out of range of understanding.

- Evaluate the pace at which content is presented. Students with advanced reasoning abilities in a subject (e.g., mathematics) may lack advanced content knowledge due to lack of prior exposure, but they may be able to master it in much less time than other students and should be given the opportunity to move at their own pace.

- Encourage the development of students' critical thinking and reasoning abilities by providing challenging opportunities for solving complex problems, particularly in knowledge domains in which students already have substantial knowledge.

- Provide students with project-based, cooperative, and situated learning opportunities to encourage innovation, creative thinking, practical skills, and social development.

- Recognize the extent to which students' social interaction within the classroom can influence cognitive development. Thus, teachers should encourage discussion, discourse, and debate that provoke thinking.

- Ensure that gifted students have opportunities to interact with other students who are at or above their cognitive reasoning and knowledge levels, whether in small groups within a heterogeneous classroom, in classes for high-ability students, or in other learning environments.

- Make students aware of, and facilitate access to, opportunities to extend their learning and to meet intellectual peers outside of the classroom. Depending on students' interests and available resources, these might include such extracurricular options as competitions, summer programs, online courses, internships, and research experiences.

- Provide students who have the reasoning abilities and the potential to excel beyond their age peers but who lack background knowledge with opportunities to fill gaps in their knowledge base and to move ahead in intellectually stimulating environments.

- Understand that students with exceptionally advanced cognitive abilities may not be similarly advanced socially and emotionally. This may impede continued cognitive development and affect educational decision making. Such students may need help with social skills development or require counseling.

- Help students whose background experiences have not familiarized them with schooling practices in their new home country adjust to the culture of the classrooms in which they are now placed.

\section{REFERENCES}

+Assouline, S. G., Colangelo, N., VanTassel-Baska, J ., \& LupkowskiShoplik, A. (Eds.). A nation empowered: Evidence trumps the excuses for holding back America's brightest students (Vol. 2). Iowa City, IA: University of Iowa, Belin-Blank Center.

Bjorklund, D. F. (2012). Children's thinking: Cognitive development and individual differences (5th ed.). Belmont, CA: Wadsworth.

Donaldson, M. (1978). Children's minds. New York, NY: Norton.

Mayer, R. E. (2008). Learning and instruction. Upper Saddle River, NJ : Pearson.

+Robinson, N. M., \& Robinson, H. B. (1982). The optimal match: Devising the best compromise for the highly gifted student. New Directions for Child and Adolescent Development, 79-94.

Rogoff, B. (2003). The cultural nature of human development. New York, NY: Oxford University Press.

+Subotnik, R. F., Olszewski-Kubilius, P., \&Worrell, F. C. (2011). Rethinking giftedness and gifted education: A proposed direction forward based on psychological science. Psychological Science in the Public Interest, 12, 3- 54. 
PRINCIPLE 4 Learning is based on context, so generalizing learning to new contexts is not spontaneous but instead needs to be facilitated.

\section{EXPLANATION}

Learning occurs in context. Contexts can consist of one or more subject-matter domains (e.g., science), specific tasks/problems (e.g., a real-world problem to solve), social interactions (e.g., caretaking routines of a parent and child), and situational/physical settings (e.g., home, classrooms, museums, labs, online). For learning to be more effective or powerful, it needs to generalize to new contexts and situations. Transfer or generalization of knowledge and skills is not spontaneous or automatic for most students. It becomes progressively more difficult for all students the more dissimilar the new context is from the original learning context. Transfer of knowledge should be facilitated, supported, and assessed given that the ability to transfer is an important indicator of the quality of student learning -its depth, adaptability, and flexibility.

By using more sophisticated strategies for learning, thinking, and problem solving than others their age, gifted students are more likely to spontaneously apply their knowledge in contexts quite different from those in which it was learned. This flexibility is the result of superior metacognitive skills and meta-memory. Gifted learners are able to use what they know more efficiently by seeking and recognizing what they already know that is relevant to unfamiliar tasks. They see connections when their peers do not, although their peers have the same knowledge. This ability to use previously learned knowledge and skills in unfamiliar tasks contributes to the rapid pace of gifted students' learning. Like their same-age peers, they can learn more and better ways to transfer and generalize, but peers will need more and different instruction, support, and practice.

\section{RELEVANCE FOR TEACHERS}

Teachers can support student transfer of knowledge and skills across contexts-from highly similar to highly dissimilar contexts. The nature and extent of the support and practice needed for students to learn to transfer and generalize will vary depending on the degree of similarity between the contexts and the ability of the learners. For example, compared to their peers, gifted students will need less assistance, less specific instruction, and less practice to apply previously learned metacognitive skills to different tasks in different subject areas. Because their learning differs from that of others their age, gifted students should work with others who share their abilities whenever possible to optimize their growth. Developing gifted students' transfer and generalization is best done by having them engage in activities that do the following:

- Include and build on students' prior knowledge and strengths. Make connections between what students know and what is to be learned.

- Provide opportunities for students to learn content in multiple contexts.

- Have students compare and contrast contexts, describing contextual similarities that will help them determine when and how to use what they know.

- Organize learning around complex underlying concepts, principles, and strategies for self-regulated learning within and across domains so it is easier to retrieve and apply in varied circumstances. Promote learning by understanding rather than focusing on surface-level information in a learning situation or by memorizing specific details. Like experts, gifted students need to organize facts around general principles. For example, while physics experts approach problem solving by way of major principles or laws that apply to the problem, novices focus on the equations and plugging numbers into these formulas.

- Apply learning to the real world. Encourage and expect students to notice and find applications of their knowledge beyond the classroom (e.g., using multiplication and division to understand the cost of purchases in a store) and help them draw on their past experiences when trying to understand academic principles. Teachers can do this frequently in multiple contexts so transfer is a part of their regular learning routine. Teachers should accommodate differences in the nature and extent of assistance individual students need. For exam- 
ple, some students may not spontaneously recognize the relevance of their learning about solving division problems unless it is applied to computing gas mileage in a real-world context while others will need only a subtle hint to see it.

- Scaffold transfer and generalization initially by guiding it, gradually reducing the teacher's role, encouraging students to take responsibility for these actions over time until they have internalized them, and use them automatically. Examples include:

- Encouraging students to share similarities they notice across contexts and discuss how they might inform their learning.

- With classmates, constructing routines and strategies they can use to know when, how, and why to generalize their learning. This will be most effective when high-ability learners do this together rather than in mixed-ability settings.

- Modeling transfer and generalization. Teachers can think aloud to externalize and demonstrate the types of self-awareness and thinking that are involved in transfer expertise.

- Solve challenging, complex, real-world problems. Over time, design a series of activities for learning that will give gifted students opportunities to apply their learning and see its relevance. The likelihood that learning will be applied beyond school increases with the authenticity of the problems. Sustained, inquiry-based learning experiences (project-, problem-, or design-based) addressing authentic problems offer high-ability learners the opportunities they need to flexibly apply and extend their knowledge and skills. Nongifted peers also benefit from these experiences but will need more time and support. These activities should include opportunities to:

- Activate prior knowledge in discussions in which students identify relevant information and skills they have already learned and seek connections with the task.

- Reflect on similarities in what and how they are learning across tasks. Focus on connec- tions and activities that can trigger transfer in the future.

- Assess transfer. Require gifted students to demonstrate the flexibility of their knowledge across contexts (subjects, tasks, interactions, and settings). High-ability learners can be expected to find more abstract and sophisticated connections and applications than their peers. Provide feedback that will enable them to enhance the depth, adaptability, and flexibility of their learning in the future.

\section{REFERENCES}

+Borkowski, J ., \& Peck, V. A. (1986). Causes and consequences of metamemory in gifted children. In R. J . Sternberg \& J . E. Davidson (Eds.), Conceptions of giftedness (pp. 182- 200). New York, NY: Cambridge University Press.

Bransford, J . D., Brown, A. L., \& Cocking, R. (Eds). (2000). How people learn. Washington, DC: National Academies Press.

+J ausovec, N. (1991). Flexible strategy use: A characteristic of gifted problem solving. Creativity Research J ournal, 4(4), 349- 366.

+Kanevsky, L. (1990). Pursuing qualitative differences in the flexible use of problem-solving strategy by young children. J ournal for the Education of the Gifted, 13, 115- 140.

Mayer, R. (2008). Learning and instruction. Upper Saddle River, NJ : Pearson.

+Parker, W., Mosborg, S., Bransford, J ., Vye, N., Wilderson, J ., \& Abbott, R. (2011). Rethinking advanced high school coursework: Tackling the depth/ breadth tension in the AP US Government and Politics course. J ournal of Curriculum Studies, 43, 533- 559.

Saxe, G. B. (1991). Culture and cognitive development: Studies in mathematical understanding. Hillsdale, NJ : Erlbaum.

+Scruggs, T. E., \& Mastropieri, M. A. (1988). Acquisition and transfer of learning strategies by gifted and nongifted students. J ournal of Special Education, 22, 153- 166.

Sousa, D.A. (2011). How the brain learns (4th ed). Thousand Oaks, CA: Corwin.

\section{PRINCIPLE 5 Acquiring long-} term knowledge and skill is largely dependent on practice.

\section{EXPLANATION}

What people know (their knowledge base) is stored in long-term memory. Most information, particularly when related to either academic content or highly 
skilled activities (e.g., sports, artistic endeavors such as playing a musical instrument), must be processed in some way before being saved in long-term memory. At any given moment, students experience an enormous amount of stimuli in the environment, but only a small portion is further processed in the form of attention and encoding, ultimately moving into a time-constrained and limited capacity memory-storage area known as short-term or working memory. To be retained more permanently, information must be transferred into long-term memory, which by definition is of relatively long duration (e.g., decades), has very large capacity, and is highly organized (e.g., categorized). The transfer of information from shortterm to long-term memory is accomplished through different strategies, and practice is key to this transfer process. ${ }^{3}$ Intelligence and talent provide the grounding for more efficient and effective use of instruction and practice. That is, many gifted students are capable of capitalizing on efficient knowledge acquisition and develop innovative mechanisms for encoding new information, retrieving knowledge, and applying skills. However, talent undeveloped by practice and rehearsal is not sufficient for acquiring expertise.

Studies comparing the performance of experts and novices have uncovered important distinctions between deliberate practice and other activities, such as "drill and kill" repetition. Rote repetition-simply repeating a task -will not by itself improve performance or longterm retention of content. Instead, deliberate practice involves attention, rehearsal, and repetition over time and leads to new knowledge or skills that can later be developed into more complex knowledge and skills. Some research has shown limited impact of deliberate practice in education, but such studies often rely on course grades and time spent on homework, two factors that are often poor indicators of success for gifted students (because typical course material may not require much effort to succeed).

Overall, evidence demonstrates that learning is improved in at least five ways through rehearsal and deliberate practice: (a) the likelihood that learning will be long term and retrievable is increased; (b) students' ability to apply elements of knowledge automatically and without reflection is enhanced; (c) skills that become automatic free up students' cognitive resourc-

${ }^{3}$ See http:// www.apa.org/ education/k12/ practice-acquisition.aspx es for learning more challenging tasks; (d) transfer of practiced skills to new and more complex problems is increased; and (e) gains often bring about motivation for more learning. The fact that gifted students often learn basic tasks more easily and quickly can reinforce their motivation for learning by allowing them to achieve automaticity with less effort. However, higher stages of skill and knowledge acquisition will inevitably require practice, concentration, and targeted experiences. This process cannot be avoided.

\section{RELEVANCE FOR TEACHERS}

Student practice can be elicited and encouraged by teachers in a variety of ways. Because practice requires intense, focused effort, students may not find it inherently enjoyable; therefore, teachers need to encourage students to practice by pointing out that expending effort leads to automaticity of basic skills and knowledge and easier access to far more interesting and creative opportunities. Teachers can motivate students by sharing examples of practice to automaticity such as driving a manual transmission car, learning a new language to fluency, playing a musical instrument, typing on a computer without looking, or mastering multiplication tables.

Unrealistic or poorly designed practice problems may increase students' frustration and decrease their motivation to attempt future practice problems. Similarly, simply giving "more of the same" work to gifted students does not necessarily constitute practice, especially if they have already mastered the material. Providing students with opportunities to apply what they know may be more fruitful. Effective methods of implementing practice in the classroom include:

- Using reviews and tests (practice testing) for mastery of basic skills and knowledge that are essential to gaining access to higher level activities. The value of testing or any kind of practice exercise is enhanced by conducting them at spaced intervals (distributive practice) and giving them frequently. Brief tests with open-ended questions are particularly effective because they require that students not only recall information from long-term memory but also generate new information from that retrieval. 
- Providing students with a schedule of repeated opportunities (interleaved practice) to rehearse and transfer skills or content by practicing with tasks that are increasingly dissimilar to the target task or using several methods to approach the same task.

- Designing tasks with students' existing knowledge in mind (see Principle 2).

- Keeping the students' "eye on the prize" of gaining access to more enjoyable and creative work once mastery is achieved.

Gifted students may have uneven profiles of ability, and practice levels and amounts of practice need to be adjusted according to their abilities and interests. Gifted students, like all students, must practice to acquire knowledge and skills they have not mastered (they just may need less time and effort), and practice should be designed to appeal to their goals and aspirations. Repetition may be particularly useful for predictable and repeated activities (e.g., memorizing the periodic table or state capitals), but less is known about optimal contributions of practice to novel and/ or complicated tasks where academic talent and specific abilities may play a much more prominent role. Regardless, experiences tailored to the specific needs of gifted students are needed to help them develop and enhance their performance.

\section{REFERENCES}

Campitelli, G., \& Gobet, F. (2011). Deliberate practice: Necessary but not sufficient. Current Directions in Psychological Science 20, 280- 285. doi:10.1177/ 0963721411421922

Dunlosky, J ., Rawson, K. A., Marsh, E. J ., Nathan, M. J ., \& Willingham, D. T. (2013). Improving students' learning with effective learning techniques: Promising directions from cognitive and educational psychology. Psychological Science in the Public Interest, 14, 4- 58. doi:10.1177/ 1529100612453266

+Macnamara, B. N., Hambrick, D. Z., \& Oswald, F. L. (2014). Deliberate practice and performance in music, games, sports, education, and professions: A meta-analysis. Psychological Science, 25, 1608- 1618. doi:10.1177/0956797614535810

+Mosing, M. A., Madison, G., Pederson, N. L., Kuja-Haikola, R., \& Ullen, F. (2014). Practice does not make perfect: No causal effect of music practice on music ability. Psychological Science, 25, 1795- 803. doi:10.1177/ 0956797614541990

Roediger, H. L. (2013). Applying cognitive psychology to education: Translational education science. Psychological Science in the Public Interest, 14, 1- 3. doi:10.1177/ 1529100612454415
Rosenshine, B., \& Meister, C. (1992). The use of scaffolds for teaching higher-level cognitive strategies. Educational Leadership, 49, 26- 33.

Simkins, S. P., \& Maier, M. H. (2008) J ust in time teaching: Across the disciplines, across the academy. Sterling VA: Stylus. van Merrienboer, J . J . G., Kirschner, P. A., \& Kester, L. (2003). Taking the load off a learner's mind: Instructional design for complex learning. Educational Psychologist, 38(1), 5- 13. doi:10.1207/s15326985EP3801 2

\section{PRINCIPLE 6 Clear, explanatory,} and timely feedback to students is
important for learning.

\section{EXPLANATION}

Student learning can be increased when students receive regular, specific, explanatory, and timely feedback on their work. Feedback that is occasional and perfunctory (e.g., saying "good job") is neither clear nor explanatory and does not increase student motivation or understanding. Clear learning goals help to increase the effectiveness of feedback to students because the comments can be directly tied to the goals, and regular feedback prevents students from getting off track in their learning. ${ }^{4}$

The evidence to support frequent feedback specifically for gifted students is more mixed. Although regular, substantive feedback is linked to achievement and motivation for all students, gifted students may benefit from less frequent pointers or comments. It is generally preferable that when gifted students are working on problem solving and open-ended tasks, they be given opportunities to work through the problem-solving process and evaluate their progress independently rather than rely solely on a teacher's external evaluation of their work. This process can lead to greater metacognitive and reflective skills and can be enhanced through the use of peer feedback. Teachers can facilitate this process by providing feedback at key stages that is clear and timely, providing scaffolding for complex tasks.

${ }^{4}$ See http:// www.apa.org/ education/ k12/ classroom-data.aspx 


\section{RELEVANCE FOR TEACHERS}

The feedback teachers offer can be most effective when it provides gifted students with specific information about their knowledge and performance as related to learning goals while also allowing them opportunities to develop metacognitive and reflective skills. For example:

- Feedback from teachers can be used to help gifted learners calibrate self-assessment of their work. Specifically, when teachers ask students to first reflect on the quality of their understanding or performance-before teachers give their own evaluations-learners can develop skill in self-assessment for learning.

- The timing of feedback is important for gifted learners, as it should be used to provide scaffolding for learners to complete complex tasks. Teachers should provide feedback at points during the learning process when students are in need of additional support-while allowing learners to discover and learn independently when appropriate.

- Formative feedback can be used sparingly during open-ended or problem-based learning projects. When students are encouraged to persevere through complex tasks, independently of external evaluation, they develop greater skills and self-reliance.

- Peer evaluation can be used to provide effective formative feedback for gifted students' progress. With proper instructional support and guidance, gifted students can provide quality feedback to peers, and this strategy can be used to help increase motivation, achievement, and metacognitive skills.

- The purpose of feedback can be explicitly determined by the teachers to aide in differentiating course difficulty for diverse learning abilities. For example, feedback in the form of questions could be used to increase the complexity of a task or provide scaffolding.

- The tone and targeting of feedback affects student motivation. Students tend to respond better if feedback minimizes negativity and addresses significant aspects of their work and understanding, in contrast to feedback that is negative in tone and focused excessively on details of student performance that are less relevant to the learning goals.

- For gifted learners engaged in long-term projects and goals, regular feedback at key benchmarks can be used to help students maintain motivation with evidence of incremental progress.

\section{REFERENCES}

Brookhart, S. M. (2008). How to give effective feedback to your students. Alexandria, VA: Association for Supervision and Curriculum Development.

Ericsson, K. A., Krampe, R. T., \& Tesch-Romer, C. (1993). The role of deliberate practice in the acquisition of expert performance. Psychological Review, 100, 363-406. doi:10.1037/ 0033295X.100.3.363

Gobet, F., \& Campitelli, G. (2007). The role of domain-specific practice, handedness, and starting age in chess. Developmental Psychology, 43, 159- 172. doi.org/ 10.1037/ 0012-1649.43.1.159

+Holt, J. E., Kinchin, G., \& Clarke, G. (2012). Effects of peer-assessed feedback, goal setting, and group contingency on performance and learning by 10- 12-year-old academy soccer players. Physical Education and Sport Pedagogy, 17, 231- 250. doi:10.10 80/ 17408989.2012.690568

Leahy, S., Lyon, C., Thompson, M., \&Wiliam, D. (2005). Classroom assessment, minute by minute, day by day. Educational Leadership, 63, 19-24.

+Miller, M. T., \& Olthouse, J . (2013). Critical thinking in gifted children's offline and online peer feedback. Contemporary Educational Technology, 4, 66- 80.

Minstrell, J . (2001). The role of the teacher in making sense of classroom experiences and effecting better learning. In S. M. Carver $\&$ D. Klahr (Eds.), Cognition and instruction: Twenty-five years of progress (pp. 121- 150). Mahwah, NJ : Erlbaum.

+Scager, K., Akkerman, S. F., Pilot, A., \&Wubbels, T. (2014). Challenging high-ability students. Studies in Higher Education, 39, 659- 679.

+Schunk, D. H., \& Swartz, C. W. (1993). Writing strategy instruction with gifted students: Effects of goals and feedback on self-efficacy and skills. Roeper Review, 15, 225- 231.

\section{PRINCIPLE 7 Students'}

self-regulation assists learning, and self-regulatory skills can be taught.

\section{EXPLANATION}

Self-regulated learning (SRL) is "an active, constructive process whereby learners set goals for their 
learning and then monitor, regulate, and control their cognition, motivation, and behavior, guided and constrained by their goals and contextual features in the environment" (Pintrich, 2000, p. 453). Self-regulatory skills can facilitate mastery of the material to be learned. Although these skills may increase over time, they are not subject only to maturation. These skills also can be taught or enhanced, specifically through direct instruction, modeling, support, and classroom organization and structure.

Two types of learning strategies are crucial for SRL: cognitive learning strategies (e.g., rehearsal, organization, and elaboration strategies) and metacognitive learning strategies (e.g., self-assessment, goal setting, and monitoring). Especially during their first years of schooling, gifted learners often achieve at high levels without relying on such learning strategies. However, when they transition into more challenging learning settings, or when they begin to work on attaining excellence in a given talent domain, SRL becomes essential for gifted learners, too.

\section{RELEVANCE FOR TEACHERS}

Teachers can integrate the instruction and practice of SRL skills into regular classroom instruction and homework. However, to ensure that all students-regardless of their cognitive abilities-will have the opportunity to profit in equal measure from SRL interventions, teachers must attend to a number of factors. Teachers should consider the following suggestions:

- Start by introducing the individual facets of SRL during instruction. This will allow students to recognize how best-practice SRL works. Teachers can, for instance, discuss with students aspects such as (a) why it is helpful to recognize one's own strengths and weaknesses when learning and studying; (b) how accurate self-assessment can help students set appropriate goals for their own learning; (c) which learning strategies can best facilitate the achievement of set learning goals; and (d) why it is important to continuously monitor oneself during strategy implementation and, when needed, make adjustments.
- Consider the curricular and extracurricular areas in which the individual aspects of SRL can be helpful with your students.

- Keep in mind that mere discussion of the aspects of SRL will not suffice. Students will only become capable of employing specific SRL skills after they have systematically practiced using the individual SRL strategy components.

- Understand that SRL practice needs to be based on concrete, authentic content from the regular curriculum. Working within authentic educational contexts is very important for helping students recognize the usefulness of the learning strategies they are practicing during their everyday school-related learning and studying. Practicing learning strategies with students should not become isolated from actual classroom instruction.

- Guide your students-in a systematic, well-structured manner-to observe the connections between their own learning behavior and their own accomplishments. This is a sine qua non for enabling students to clearly recognize the usefulness of SRL. When designed accordingly, learning journals and daily worksheets, for example, can be very effective at opening students' eyes to their own performance improvements and the connections between their learning efforts and use of specific strategies and their achievements.

- Provide all your students with learning situations for SRL that are tailored to their respective achievement levels and, thereby, create authentic opportunities for each and every student to experience the benefits of SRL. Only when an SRL intervention succeeds in offering learning content that is appropriate for students of differing achievement levels will all students be able to realize that improving their learning behavior leads to higher achievements. For gifted students, this means that teachers must carefully craft tasks that are sufficiently challenging and engaging.

- Apply SRL strategies in as many subjects as possible. Experiencing a variety of authentic learning contexts in which students work with SRL strategies is important for transferring those strategies to as many different learning contexts as possible. 
This can increase the likelihood that newly acquired SRL strategies will remain permanently in a learner's repertoire of learning and study skills.

\section{REFERENCES}

+De Corte, E. (2013). Giftedness considered from the perspective of research on learning and instruction. High Ability Studies, 24, 3- 19. doi:10.1080/ 13598139.2013.780967

Diamond, A., Barnett, W. S., Thomas, J ., \& Munro, S. (2007, Nov. 30). Preschool program improves cognitive control. Science, 318(5855), 1387- 1388. doi:10.1126/ science.1151148

Galinsky, E. (2010). Mind in the making: The seven essential life skills every child needs. New York, NY: HarperCollins.

+Pintrich, P. R. (2000). The role of goal orientation in self-regulated learning. In M. Boekaerts, P. R. Pintrich, \& M. Zeidner (Eds.), Handbook of self-regulation (pp. 451- 502). San Diego, CA: Academic Press.

+Sontag, C., \& Stoeger, H. (2015). Can highly intelligent and high-achieving students benefit from a training of self-regulated learning in a regular classroom context? Learning and Individual Differences, 41, 43- 53. doi:10.1016/j.lindif.2015.07.008

+Stoeger, H., Fleischmann, S., \& Obergriesser, S. (2015). Self-regulated learning (SRL) and the gifted learner in primary school: The theoretical basis of and empirical findings on a research program dedicated to ensuring that all students learn to regulate their own learning. Asia Pacific Education Review, 16, 257- 267. doi:10.1007/ s12564-015-9376-7

+Stoeger, H., \& Sontag, C. (2012). How gifted students learn: A literature review. In A. Ziegler, C. Fischer, H. Stoeger, \& M. Reutlinger (Eds.), Gifted education as a lifelong challenge: Essays in honour of Franz J . Mönks (pp. 315- 336). Münster, Germany: LIT.

Wolters, C. A. (2011). Regulation of motivation: Contextual and social aspects. Teachers College Record, 113, 265- 283.

Zimmerman, B. J . (2002). Becoming a self-regulated learner: An overview. Theory Into Practice, 41(2), 64- 70.

Zumbrunn, S., Tadlock, J ., \& Roberts, E. D. (2011). Encouraging self-regulated learning in the classroom: A review of the literature. Retrieved from http:// www.self-regulation.ca/ uploads/ 5/ 6/2/6/56264915/ encouraging_self_regulated_learning_in_the_classroom.pdf

\section{PRINCIPLE 8 Student creativity}

\section{can be fostered.}

Creativity-defined as the generation of ideas that are new and useful in a particular situation-is a critical skill for students in the information-driven economy of the 21st century. Being able to identify problems, generate potential solutions, evaluate the effectiveness of those strategies, and then communicate with others about the value of the solutions are all highly relevant to educational success, workforce effectiveness, and quality of life. Creative approaches to teaching can inspire enthusiasm and joy in the learning process by increasing student engagement and modeling of real-world application of knowledge across domains. Contrary to the conventional wisdom that creativity is a stable trait (you either have it or you don't), creative thinking can be developed and nurtured in students, making it an important outcome of the learning process for students and educators.

The role of creativity in relation to giftedness and gifted education is viewed variously-with some seeing creativity as a separate but related construct from giftedness; others seeing it as a component of giftedness; and still others seeing it as a subcategory of some other trait, such as intelligence, that contributes to giftedness. Care must be taken to assess creativity in a manner that is consistent with a particular perspective when creativity is used as a criterion for identifying students as gifted.

Creativity is also often viewed as an important outcome of gifted education programs, usually focusing on increasing the cognitive creative skills of identified gifted students. The focus in gifted programs, especially at the elementary school level, is typically to develop general creativity abilities; however, some evidence indicates that creativity is better developed within a specific domain such as math, science, or the arts. Any efforts to improve creativity in students must be done within an environment that promotes divergent points of view and fosters intrinsic motivation. Although training in any number of creative thinking strategies may be beneficial, gifted students are more likely to benefit from an emphasis on problem-identification abilities (i.e., adeptness at sensing and generating opportunities or challenges-previously known or novelthat require new and useful approaches) rather than working on preestablished problems.

\section{RELEVANCE FOR TEACHERS}

Educators should be aware of the role of creativity in the official and operational definitions of giftedness for a particular school context. This may be defined in state rules, district policy, or school procedures: 
- Educators should recognize the consistency between stated conceptions of giftedness and creativity and the instruments used to assess these constructs, raising questions where alignment is unclear or questionable.

- Educators should familiarize themselves with processes for proctoring assessments (i.e., standardization) used to assess creativity and the interpretation of scores generated.

- Teachers need to observe student behaviors carefully and continuously to detect those students who show potential for high levels of creative productivity.

- When gifted programs have an established goal of growth in creative thinking, teachers should advocate for the inclusion of students with high creativity in those programs, even if those students may not meet other identification criteria, such as aptitude or achievement test performance.

Establishing a classroom environment conducive to creative thinking can be accomplished in a variety of ways ${ }^{5}$ :

- Educators can allow for a wide range of student approaches to completing tasks and solving problems, as the strategies being taught may not be the only ways to answer a specific question.

- Teachers should emphasize the value of diverse perspectives as fuel for discussion, reinforcing that such perspectives are clearly valued and not penalized in the classroom.

- Teachers should downplay the use of rewards and praise for students' creative efforts, focusing instead on the intrinsic value of the creative experience to the student and the application of real-world criteria for creative products (e.g., appropriateness to the problem, novelty, usefulness).

- Teachers should avoid the tendency to see highly creative students as disruptive; instead, student enthusiasm can be channeled into solving real-world problems or taking leadership roles on certain tasks.

\footnotetext{
${ }^{5}$ See http:// www.apa.org/ education/k12/ creativity-module.aspx
}

- Teachers themselves should model the characteristics of creative individuals in their own lives and in their teaching (e.g., taking well-considered risks, being open to new experience, persisting in the face of failure, developing tolerance for ambiguity).

The creative process is often misconstrued as being purely spontaneous or even frivolous, yet extensive research provides evidence that creativity and innovation are the result of disciplined thinking. For this reason, teachers can employ instructional strategies that can foster creativity by:

- Including prompts in assignments such as create, invent, discover, imagine, or predict and explicitly instructing students in what these prompts entail cognitively and productively.

- Exploring the professional literature for specific strategies or creative thinking skills models that can be the basis for explicitly teaching creative approaches to problem solving.

- Evaluating with students any strategies discovered for their suitability for application within an academic or artistic domain.

- Explicitly teaching methods for discovering problems that require creative solutions-including awareness of world, national, and local issues; openness to experience; a questioning attitude toward the status quo; and sensitivity to the bigger issues that might be represented by personal concerns.

- Using methods that focus on questioning, challenging prevailing beliefs, making unusual connections, envisioning radical alternatives, and critically exploring ideas and options.

- Providing opportunities for students to identify and solve authentic problems individually or in groups and to communicate their creative ideas to a wide range of audiences (e.g., peers, teachers, community members), preferably to audiences that are clearly stakeholders in the problem addressed. 
- Modeling creative processes. Teachers are powerful models, and, as such, they should share with students their own creativity-including the use of multiple strategies to identify and solve problems across various aspects of their lives. This modeling can also involve examples of how creativity is not necessary in all situations, which may help students develop an improved sense of confidence in their judgment as to when it is appropriate to focus on getting one right answer and when to pursue alternative approaches.

\section{REFERENCES}

Beghetto, R. A. (2013). Killing ideas softly? The promise and perils of creativity in the classroom. Charlotte, NC: Information Age Press.

+Hennessey, B. A., \&Amabile, T. (2004). Developing creativity in gifted children: The central importance of motivation and classroom climate (Research Monograph Series RM04202). Storrs, CT: University of Connecticut, National Research Center on the Gifted and Talented.

+Hunsaker, S. L. (2005). Outcomes of creativity training programs. Gifted Child Quarterly, 49, 292- 299. doi:10.1177/001698620504900403

+Kaufman, J . C., \&Baer, J . (Eds.). (2005). Creativity across domains: Faces of the muse. Mahwah, NJ : Erlbaum.

Kaufman, J . C., \& Beghetto, R. A. (2013). In praise of Clark Kent: Creative metacognition and the importance of teaching kids when (not) to be creative. Roeper Review: AJ ournal on Gifted Education, 35, 155- 165. doi:10.1080/ 02783193.2013.799413

+Kim, M. K., Rho, I. S., \& Cho, M. K. (2016). Creativity of gifted students in an integrated math-science instruction. Thinking Skills and Creativity, 19, 38-48. doi:10.1016/j.tsc.2015.07.004

+Mann, E. L. (2006). Creativity: The essence of mathematics. J ournal for the Education of the Gifted, 30, 236-260. doi:10.4219/ jeg-2006-264

+Miller, A. L. (2012). Conceptualizations of creativity: Comparing theories and models of giftedness. Roeper Review, 34, 94- 103. doi:10.1080/02783193.2012.660683

+Pang, W. (2015). Promoting creativity in the classroom: A generative view. Psychology of Aesthetics Creativity and the Arts, 9, 122- 127. doi:10.1037/ aca0000009

Plucker, J ., Beghetto, R. A., \& Dow, G. (2004). Why isn't creativity more important to educational psychologists? Potentials, pitfalls, and future directions in creativity research. Educational Psychologist, 39, 83- 96. doi.10.1207/s15326985ep3902_1

+Pyryt, M. C. (1999). Effectiveness of training children's divergent thinking: A meta-analytic review. In A. S. Fishkin, B. Cramond, \&P. Olszewski-Kubilius (Eds.), Investigating creativity in youth: Research and methods (pp. 351- 366). Cresskill, NJ : Hampton Press.

+Runco, M. A., \& Nemiro, J. (1994). Problem finding, creativity, and giftedness. Roeper Review, 16, 235- 241.
Runco, M. A., \& Pritzker, S. R. (Eds.). (2011). Encyclopedia of creativity (2nd ed.). Boston, MA: Academic Press.

Sternberg, R. J ., Grigorenko, E. L., \& Singer, J . L. (Eds.). (2004). Creativity: From potential to realization. Washington, DC: American Psychological Association. 


\section{What motivates students?}

PRINCIPLE 9 Students tend to enjoy learning and to do better when they are more intrinsically rather than extrinsically motivated to achieve.

\section{EXPLANATION}

Intrinsic motivation refers to engaging in an activity for its own sake. To be intrinsically motivated means to feel both competent and autonomous (e.g., I can do it for myself). Students who are intrinsically motivated work on tasks because they find them enjoyable. In other words, participation is its own reward and is not contingent on tangible rewards such as praise, grades, or other external factors. In contrast, students who are extrinsically motivated engage in learning tasks as a means to an end, such as to get a good grade or praise from their parents or to avoid punishment. It is not the case that intrinsic and extrinsic motivation are at opposite ends of a motivation continuum, such that having more of one means having less of the other. Instead, students engage in academic tasks for both intrinsic and extrinsic reasons (e.g., because they enjoy it and to get a good grade). Nonetheless, intrinsically motivated task engagement is not only more enjoyable, it is positively related to more enduring learning, achievement, and perceived competence and is negatively related to anxiety.

These benefits occur because students who are intrinsically motivated are more likely to approach their tasks in ways that enhance learning, such as attending more closely to instruction, organizing new information effectively, and relating it to what they already know. They also feel more self-efficacious and are not burdened by achievement anxiety. On the other hand, students who are more extrinsically motivated may be so focused on the reward (e.g., getting a high grade) that learning is superficial (e.g., the student may resort to shortcuts such as only skimming the reading for specific terms rather than absorbing the entire lesson), or they may become discouraged if the pressures are too high. Furthermore, externally motivated students tend to disengage once the external rewards are no longer provided, whereas intrinsically motivated students show more long-lived mastery of learning goals. ${ }^{6}$

Notably, however, a substantial body of experimental research studies shows that extrinsic motivation, when properly used, is very important in producing positive educational outcomes. Research also shows that students develop academic competence, especially with necessary lower level skills, when they do tasks repeatedly in carefully constructed ways so the basic skills become automatic (see Principle 5). As more basic skills become automatic, the tasks require less effort and are more enjoyable. J ust as in sports, students improve their reading, writing, and mathematics skills when they do these activities repeatedly with teacher guidance and feedback, gradually progressing from less complex tasks to more difficult ones. Students' engagement in these activities often requires teacher encouragement and praise for making progress. As students develop increasing competence, the knowledge and skills that have been developed provide a foundation to support the more complex tasks, which become less effortful and more enjoyable. When students have reached this point, learning often becomes its own intrinsic reward.

Research indicates that gifted students are often more "intrinsic" in their motivation than other students, at least when it comes to academic and intellectual

${ }^{6}$ See also http:/ / www.apa.org/ education/k12/ learners.aspx 
activities. They score higher on formal measures of intrinsic motivation for learning and academics, and they profess more enjoyment of thinking and learning. Gifted students' better performance when intrinsically motivated depends to some extent on the level of challenge involved in the work. Gifted students who are compliant may do equally well under either motivational condition on classwork that is easy for them, but when encountering appropriately challenging work, they may perform much better when intrinsically motivated. With respect to gifted students who are considered underachievers, there is evidence that some are highly intrinsically motivated to learn, but not necessarily in areas that are recognized in regular school classes. Finally, like other students, gifted students engage in tasks for both intrinsic and extrinsic reasons; with contests and competitions, in particular, some students may be intrinsically motivated to engage in competition as well as extrinsically motivated to win.

\section{RELEVANCE FOR TEACHERS}

Most general advice for engaging and increasing the intrinsic motivation of students applies to gifted students as well. However, there are some unique characteristics and needs of gifted students that require special attention. The most common barrier to intrinsic motivation for gifted students during the school day is that they are probably not working on material that is optimally challenging for them (see Principle 12). Students who are extrinsically motivated by good grades and who are generally compliant will do enough work to receive an A whether the work is too easy or not. Students who rebel against what they perceive as "busywork" may hurriedly complete too-easy work with careless errors or fail to do it at all. In both cases, the student is not developing good work habits or putting forth the level of effort required to master new content and skills. Those who have run fast-paced, challenging summer or school-year programs for gifted students know that students who have consistently received easy As often need remediation in study skills.

Another barrier to the development of intrinsic motivation is that gifted students are often praised by parents and educators for completing work quickly and easily, as well as for receiving the highest grade or winning a competition. Although it is hard to argue against praising success, that kind of praise may put gifted students at risk of valuing performance goals over mastery goals (see Principle 10). Praise for effort, for learning new, challenging material, and for mastering new skills is likely to lead to mastery goals, which are more aligned with intrinsic motivation. Asking gifted students "What did you learn?" rather than "What did you get?" can also help with the development of intrinsic motivation.

Promoting intrinsic motivation in any student requires the incorporation of practices and activities that support students' fundamental need to feel competent and autonomous. The three suggestions below apply to gifted students with some special considerations:

- When using grades, teachers might want to highlight their informational (feedback) rather than controlling (rewarding/punishing) function. With gifted students, teachers might want to provide information not just on how well the student did compared with others but also offer some choices regarding what else the student could do with the assignment that might take it to another level of challenge or identify areas in which the student has particularly shown improvement or growth.

- When using any external constraints such as deadlines, a useful strategy is for teachers to think about whether the constraints will be perceived as too controlling. Autonomy needs are more likely to be satisfied when students have choices. Allowing students to select from an array of achievement activities and to have a role in establishing rules and procedures helps to foster perceptions of autonomy. Tasks are optimally challenging when they are neither too easy nor too hard. Gifted students who are not used to being challenged by academic activities may need guidance and encouragement to choose tasks they are not sure they can accomplish quickly and easily.

- Because intrinsic motivation involves enjoying a task for its own sake, teachers might want to organize learning activities following the ideas presented for Principle 8 (on creativity) so as to introduce novelty by providing some level of surprise or incongruity and allowing for creative problem solving. Small groups can be an excellent structure for promoting creative problem solving. Flexible grouping, where students of similar abilities and/ or 
interests are at least sometimes grouped together, is more likely to lead to intrinsic motivation. Gifted students need to be challenged and excited by the ideas of students who share their passions or who disagree with them competently and effectively.

Supporting students' intrinsic motivation to achieve does not mean that teachers should completely eliminate the use of rewards. Certain tasks in the classroom and in life, like practicing new skills, are going to be inherently uninteresting to students. It is important to teach students that some tasks, even tasks that are necessary to master, might be uninteresting at first yet require consistent, sometimes tedious, engagement for learning. This is also critical for gifted students, who may not have learned the level of hard work and practice that is required to demonstrate excellence. Once learned, new skills may become their own reward.

\section{REFERENCES}

Anderman, E. M., \& Anderman, L. H. (2014). Classroom motivation (2nd ed.). Boston, MA: Pearson.

Brophy, J . (2004). Motivating students to learn. Mahwah, NJ : Erlbaum.

Brophy, J ., Wiseman, D. G., \& Hunt, G. H. (2008). Best practice in motivation and management in the classroom (2nd ed.). Springfield, IL: Charles C Thomas.

+Clinkenbeard, P. R. (2012). Motivation and gifted students: Implications of theory and research. Psychology in the Schools, 49, 622- 630 .

+Csikszentmihalyi, M., Rathunde, K., \&Whalen S. (1993). Talented teenagers: The roots of success and failure. Cambridge, UK: Cambridge University Press.

Deci, E. L., \& Ryan, R. M. (1985). Intrinsic motivation and self-determination in human behavior. New York, NY: Plenum.

+Feldhusen, J . F., Dai, D. Y., \& Clinkenberd, P. R. (2000). Dimensions of competitive and cooperative learning among gifted learners. J ournal for the Education of the Gifted, 23, 328- 342.

Gottfried, A. E., \& Gottfried, A. W. (1996). A longitudinal study of academic intrinsic motivation in intellectually gifted children: Childhood through early adolescence. Gifted Child Quarterly, 40, 179- 183.

+Olszewski-Kubilius, P. M., Kulieke, M. J ., \& Krasney, N. (1988). Personality dimensions of gifted adolescents: A review of the empirical literature. Gifted Child Quarterly, 32, 347- 52.

Thorkildsen, T. A., Golant, C. J ., \& Cambray-Engstrom, E. (2008). Essential solidarities for understanding Latino adolescents' moral and academic engagement. In C. Hudley \&A. E. Gottfried (Eds.), Academic motivation and the culture of schooling in childhood and adolescence (pp. 73- 89). Oxford, UK: Oxford University Press.
PRINCIPLE 10 Students persist in the face of challenging tasks and process information more deeply when they adopt mastery goals rather than performance goals.

\section{EXPLANATION}

Goals are the rationale for why students engage in particular learning activities. Researchers have identified two broad types of goals: mastery goals and performance goals. Mastery goals are oriented toward acquiring new skills or improving levels of competence or expertise. Students who hold mastery goals are generally motivated to learn new skills or achieve mastery in a content area or on a task. In contrast, students, including gifted students, who adopt performance goals are motivated to complete tasks to demonstrate they have adequate ability or to avoid difficult tasks in an effort to conceal fears of being "unmasked" as not gifted. According to this analysis, individuals can engage in achievement activities for divergent reasons: They may strive to develop competence and expertise by learning as much as they can (mastery goals), or they may strive to display their competence or expertise by trying to outperform others (performance goals). Performance goals can lead to students' avoiding challenges if they are overly concerned about how they will perform compared with other students. In typical classroom situations in which students encounter challenging materials, mastery goals are generally more useful than performance goals.

Although mastery goals may be preferred in many contexts and have been shown to lead to better outcomes for a variety of learning and motivation factors, there are some situations in which performance goals may be more useful or appropriate. For example, gifted students often participate in contests and competitions where performance is the point of the activity. They may well value the learning, mastery, and expertise that led them to the competition, but the short-term goal in that competition is a performance goal. To be able to develop their full potential, gifted students need a multifaceted motivational strategy that matches the 
goal to the task. Several studies show that goals related to mastering task demands (mastery motivation) and outperforming others (performance motivation) are not mutually exclusive. In the case of gifted students, performance goals can hardly be accomplished without mastery goals, because when exceptional achievement is expected, it calls for considerable interest, task engagement, effort, and deep learning of the given material. To be an exceptionally high achiever, a complex interaction between different motives and goals is needed.

There is a close relationship between mastery/ performance goals and "mindset." Students who believe that intelligence is a fixed commodity (as many students who have been formally identified as "gifted" might well believe) are more likely to hold performance goals, either to demonstrate high intelligence or to hide (performance avoidance) what they believe to be an inadequate level of ability. Students who believe that intelligence is enhanced as they learn are more likely to demonstrate mastery goals.

\section{RELEVANCE FOR TEACHERS}

Teachers can organize instruction to foster mastery goals in the following ways:

- Emphasize individual effort, current progress over past performance, and improvement when evaluating student work more than relying on normative standards and comparison with others. ${ }^{7}$

- Try to avoid social comparisons. In classroom settings, student evaluations are best delivered privately to focus attention on personal growth and discourage attention to comparisons among student performance. Whereas high-achieving students often enjoy public recognition of their accomplishments, those who are struggling in a particular area or who worry about appearing "not gifted" can be discouraged by social comparisons. Also, students who routinely perform better than peers may worry about being socially stigmatized if praised in public.

\footnotetext{
${ }^{7}$ See http:// www.apa.org/ education/k12/ using-praise.aspx
}

- Giving praise like "perfect," "brilliant," and "amazing" that provides no specific information to the student about what was done well is best avoided because it does not promote guidance for replicating high-quality work and reflects a performance orientation.

- Encourage students to see mistakes or wrong answers as opportunities to learn rather than as sources of evaluation or evidence of inadequate ability. If teachers focus too much attention on perfect scores or make student mistakes too visible or onerous (e.g., red marks on students' papers), then students may become discouraged from attempting challenging tasks. Mistakes due to misunderstandings (rather than to lack of effort) should be discussed rather than penalized.

- Individualize the depth and pacing of instruction as much as possible. Some students finish in-class work much more quickly than others and should be encouraged to tackle appropriately challenging projects or tasks in which they have some choice. Allowing students a role in setting timelines for completing tasks and monitoring their own progress helps them focus on process (acquiring mastery) in addition to outcome (performance). If students spend most of their time on work that is easily completed, they are unlikely to develop the work ethic that is necessary to master challenges and develop expertise, and this can lead to underachievement.

- When using cooperative learning, vary the composition of student groups. Although mixed-ability groups are often recommended in the literature (typically a high achiever, a low achiever, and two average achievers), a student who is always the highest performer in a group may not get the opportunity to stretch intellectually and to master new skills. Sometimes gifted students need to work with their peers toward a common goal to develop mastery as part of a team. 


\section{REFERENCES}

Ames, C. (1992). Classrooms: Goals, structures, and student motivation. J ournal of Educational Psychology, 84, 261- 271.

Anderman, L. H., \&Anderman, E. M. (2009). Oriented towards mastery: Promoting positive motivational goals for students. In R. Gilman, E. S. Huebner, \& M. Furlong (Eds.), Handbook of positive psychology in the schools (pp. 161- 173). New York, NY: Routledge.

Deci, E. L., \& Ryan, R. M. (2002). The paradox of achievement: The harder you push, the worse it gets. In J . Aronson (Ed.), Improving academic achievement: Impact of psychological factors in education (pp. 62- 90). San Diego, CA: Academic Press.

+Dweck, C. S. (2012). Mindsets and malleable minds: Implications for giftedness and talent. In R. Subotnik, A. Robinson, C. Callahan, P. J ohnson, \&E. J . Gubbins (Eds.), Malleable minds: Translating insights from psychology and neurosciences to gifted education (pp. 7- 18). Storrs, CT: University of Connecticut, National Research Center on the Gifted and Talented.

+Elliot, A. J ., \& Trash, T. M. (2001). Achievement goals and the hierarchical model of achievement motivation. Educational Psychologist, 13, 139- 156.

+Gottfried, A. W., Gottfried, A. E., Guerin, D. W. (2006) The Fullerton Longitudinal Study: A long-term investigation of intellectual and motivational giftedness. J ournal for the Education of the Gifted. 29(4), 430-450.

Graham, S. (1990). On communicating low ability in the classroom: Bad things good teachers sometimes do. In S. Graham \& V. Folkes (Eds.), Attribution theory: Applications to achievement, mental health, and interpersonal conflict (pp. 17-36). Hillsdale, NJ : Lawrence Erlbaum.

+McCoach, D. B., \& Siegle, D. (2003). Factors that differentiate underachieving gifted students from high-achieving gifted students. Gifted Child Quarterly, 47(2), 144- 154.

Meece, J . L., Anderman, E. M., \&Anderman L. H. (2006). Classroom goal structure, student motivation, and academic achievement. Annual Review of Psychology, 57, 487- 504. doi:10.1146/ annurev.psych.56.091103.070258

+Vansteenkiste, M., Lens, W., Elliot, A. J ., Soenens, B., \& Mouratidis, A. (2014). Moving the achievement goal approach one step forward: Toward a systematic examination of the autonomous and controlled reasons underlying achievement goals. Educational Psychologist, 49, 153- 174.

\section{PRINCIPLE 11 Teachers' expec-} tations about their students affect students' opportunities to learn, their motivation, and their learning outcomes.

\section{EXPLANATION}

Teachers tend to hold expectations about the abilities and academic achievement of their students. These beliefs shape the kinds of instruction delivered to students, the grouping practices used, the learning outcomes anticipated, and the methods used for evaluation. Most teacher expectations about individual student ability are based on students' past academic performance and, for the most part, may be an accurate representation. In some cases, however, teachers come to hold inaccurate beliefs, such as expecting less of the student than he or she can actually achieve. If faulty expectations are communicated to a student (whether verbally or nonverbally), that student may begin to perform in ways that confirm the teacher's original expectation. An inaccurate teacher expectation that creates its own reality has been labeled a self-fulfilling prophecy. When these inaccurate expectations do occur, they are more likely to be directed toward stigmatized groups (e.g., ethnic minority students, economically disadvantaged students, twice-exceptional students, gender groups), because negative beliefs or stereotypes about the intellectual abilities of these groups exist in our society.

These faulty expectations are more likely to occur in the earlier grades, at the beginning of a school year, and at times of school transitions-in other words, when the contexts in which information about prior achievement may be least available or reliable and when students may have grounds to question their abilities. Once these expectations are formed, teachers may maintain them, even in the presence of counterevidence.

Whether accurate or not, expectations influence how teachers treat students. For example, teachers appear to provide a more supportive emotional climate, clearer feedback, more attention, more instructional time, more choice, and more challenging learning opportunities overall for their high-expectancy versus low-expectancy students. Such differential treatment may increase the actual differences in achievement between high- and low-performing gifted students over time, although all gifted students do not respond equally to these inaccurate teacher expectations. Depending on their personality traits, some students will take teacher expectations as a challenge and cope with them, whereas others may show a decrease in academic performance. With training, teachers can become more 
accurate in identifying gifted students and in forming expectations about them. Teachers should be well acquainted with the typical behavior, preferences, and interests of the gifted students in their classes, respond to them appropriately, and avoid basing their expectations solely on the past achievements of other gifted students with whom they have worked.

\section{RELEVANCE FOR TEACHERS}

It is best for teachers to communicate high expectations to all students and maintain appropriately high standards for everyone to avoid negative self-fulfilling prophecies:

- Teachers can continually assess the reliability of the information they are using to form their expectations. A student's weak academic history should not be perceived as the absolute last word about a student (i.e., there may be mitigating factors that may have impaired the student's ability in the past but no longer apply), but rather as a working hypothesis about a student that the teacher has an opportunity to disprove. Also, race, gender, and social class are not solid bases on which to form expectations of student ability or achievement.

- Because teachers can sometimes be unaware they are treating students differently on the basis of their expectations (high-expectancy students vs. low-expectancy students), it can be helpful for teachers to do a self-check. For example, teachers can ask themselves whether (a) only high expectancy students are seated in the front of the classroom, (b) everyone is getting a chance to participate in class discussions, and (c) written feedback on assignments is comparably detailed for highand low-expectancy students. Such self-checks are also important when referring students for gifted programming.

- It is essential that teachers hold high expectations of gifted students, but having too many high expectations is not always motivating for gifted students, especially when those expectations are in areas of little interest to the student, the student has too many talents and too little time to attend fully to all of them, or teachers expect high performance in areas in which the student has more average abil- ity. Such situations can gradually result in student discontent, a decline in her or his interests, a lack of focus on learning and mastery of learning skills, lowered responsibility for her or his own learning and learning outcomes, and weaker academic self-confidence.

- Teachers should discuss and explain the reasoning underlying their expectations with students and their parents. It is important that parents understand the positive and negative effects of their own and others' expectations on their children. Students should be provided with clear feedback when these expectations have been met. Teachers should encourage gifted students to gradually generate and self-regulate their expectations regarding their learning and academic achievements.

- When formulating and communicating high expectations to gifted students, teachers need to consider the social context. It is likely that gifted students will not want to fulfill expectations that will alienate them from their classmates and make them feel "too different."

- Teachers should note that their high expectations toward gifted students are typically appropriate; however, they must also be able to respond appropriately by providing constructive feedback when gifted students perform poorly and/ or fail to satisfy teachers' high expectations. Even the most exceptional individuals occasionally struggle or fail, so it is essential for teachers to be flexible and able to adapt expectations to specific situations.

- Along with having high expectations, teachers will have to guide gifted students in how to meet expectations. High expectations require extraordinary efforts from gifted learners and can be fulfilled with appropriately challenging activities and support.

- Probably the best antidote to negative expectancy effects is to never give up on a student.

\section{REFERENCES}

+Garrett, L., Rubie-Davies, C., Alansari, M., Peterson, F., Flint, A., Watson, P., \& McDonald, L. (2015). "Missing out”? The potential consequences of inaccurate teacher expectations on young gifted 
readers' achievement outcomes. APEX: The New Zealand J ournal of Gifted Education, 19.

J ussim, L., Eccles, J ., \&Madon, S. (1996). Social perception, social stereotypes, and teacher expectations: Accuracy and the quest for the powerful self-fulfilling prophecy. In M. P. Zanna (Ed.), Advances in experimental social psychology (Vol. 28, pp. 281- 388). San Diego, CA: Academic Press.

J ussim, L., \& Harber, K. D. (2005). Teacher expectations and self-fulfilling prophecies: Knowns and unknowns, resolved and unresolved controversies. Personality and Social Psychology Review, 9, 131- 155.

J ussim. L., Robustelli, S., \& Cain, T. (2009). Teacher expectations and self-fulfilling prophecies. In A. Wigfield \& K. Wentzel (Eds.), Handbook of motivation at school (pp. 349- 380). Mahwah, NJ : Erlbaum.

+Missett, T. C., Azano, A. P., Callahan, C. M., \&Landrum, K. (2016). The influence of teacher expectations about twice-exceptional students on the use of high quality gifted curriculum: A case study approach. Exceptionality, 24, 18- 31.

+Missett, T. C., Brunner, M. M., Callahan, C. M., Moon, T. R., \&Azano, A. P. (2014). Exploring teacher beliefs and use of acceleration, ability grouping, and formative assessment. J ournal for the Education of the Gifted, 37, 245- 268.

+Moltzen, R. (2011). Underachievement. In R. Moltzen (Ed.), Gifted and talented: New Zealand perspectives (3rd ed., pp. 403-433). Auckland, New Zealand: Pearson Originals.

+Rubie-Davies, C. M. (2015). Becoming a high expectation teacher: Raising the bar. New York, NY: Routledge.

Schunk, D. H., Meece, J . L., \& Pintrich, P. R. (2014). Motivation in education: Theory, research, and applications. Boston, MA: Pearson.

Stipek, D. J. (2002). Motivation to learn: Integrating theory and practice (4th ed.). New York, NY: Allyn \& Bacon.

+Weinstein, R. S. (2002). Reaching higher: The power of expectations in schooling. Cambridge, MA: Harvard University Press.

\section{PRINCIPLE 12 Setting goals}

that are short-term (proximal), specific, and moderately challenging enhances motivation more than establishing goals that are longterm (distal), general, and overly challenging.

\section{EXPLANATION}

Goal setting is the process by which a person establishes a standard of performance (e.g., "I want to learn 10 new words every day"; "I want to graduate from high school in 4 years"). This process is important for motivation because students with a goal and adequate self-efficacy are likely to engage in activities that lead to attainment of that goal. Self-efficacy is also increased as students monitor the progress they are making toward their goals, especially when they are acquiring new skills in the process.

Three properties of goal setting are important for motivation. First, short-term or proximal goals are more motivating than long-term or distal goals because it is easier to judge progress toward proximal goals. Developmentally, at least until middle adolescence, students tend to be less skilled at thinking concretely about the distant future. Second, specific goals (e.g., "I will finish 20 additional facts today with $100 \%$ accuracy) are preferable to more general goals (e.g., "I will try to do my best"), because they are easier to quantify and monitor. Third, moderately difficult goals rather than very hard or very easy goals are the most likely to motivate students because moderately difficult goals typically will be perceived as challenging but attainable.

Gifted students, however, may set serious long-term or distal goals, particularly within a domain of talent (e.g., "I want to be a professional musician") and may develop the capacity to think concretely about the distant future at an earlier age than typical peers. Thus, gifted students may be able to participate in long-term goal setting in congruence with earlier transitions to developing the capacity for abstract thought. Additionally, among gifted students, high levels of intrinsic motivation and/or academic talent may allow for setting difficult goals and achieving them. These need to be supported by parents and teachers, as some areas of giftedness will require longterm planning and support.

\section{RELEVANCE FOR TEACHERS}

Research has documented the benefits of proximal, specific, and moderately challenging goals on achievement outcomes, but gifted students may have the capacity for setting long-term goals, and their higher levels of intrinsic motivation and/ or academic talent may allow for setting difficult goals. Students need to be provided with many opportunities to set short-term, specific, and moderately difficult goals in their classroom work: 
- Keeping a written record of goal progress that is regularly checked by both the student and the teacher is especially desirable.

- As students become proficient at setting moderately challenging proximal goals, they will learn to become intermediate risk takers (not aspiring too low or too high), which is one of the most important characteristics of achievement-oriented individuals.

- Differentiation in the classroom can be applied to goal-setting conversations and activities. If gifted students are able to focus on, and grasp, longer term goals than their peers, teachers can meet their needs through differentiating goal-setting concepts and encouraging higher level executive functioning techniques.

- Specific feedback can help make students' goals more effective. Teachers should provide regular feedback to students during the goal-setting process so they are able to modify their efforts and their goals. Feedback also helps keep students on target and aware of time constraints (see Principle $6)$.

\section{REFERENCES}

Anderman, E. M., \& Wolters, C. (2006). Goals, values, and affect: Influences on student motivation. In P. A. Alexander \& P. Winne (Eds.), Handbook of educational psychology (2nd ed., pp. 369- 389). Mahwah, NJ : Erlbaum.

+Carter, K., \& Ormrod, J . (1982). Acquisition of formal operations by intellectually gifted children. Gifted Child Quarterly, 26, $110-114$.

+Chan, D. W. (2008). Goal orientations and achievement among Chinese gifted students in Hong Kong. High Ability Studies, 19, 37- 51.

Locke, E. A., \& Latham, G. P. (2002). Building a practically useful theory of goal setting and task motivation: A 35-year odyssey. American Psychologist, 57, 705- 717. doi:10.1037// 0003066X.57.9.705

+Malpass, J . R., O’Neil, H. F., J r., \& Hocevar, D. (1999). Self-regulation, goal orientation, self-efficacy, worry, and high-stakes math achievement for mathematically gifted high school students. Roeper Review, 21, 281- 289.

Martin, A. J . (2013). Goal-setting and personal best goals. In J . Hattie \& E. M. Anderman (Eds.), International guide to student achievement (pp. 356- 358). New York, NY: Routledge.

+Risemberg, R., \&Zimmerman, B. J . (1992). Self-regulated learning in gifted students. Roeper Review, 15, 98- 101.
Schunk, D. H. (1989). Self-efficacy and achievement behaviors. Educational Psychology Review, 1, 173-208. doi:10.1007/ BF01320134

Schunk, D. H., \&Zimmerman, B. J . (2006). Competence and control beliefs: Distinguishing means and ends. In P. A. Alexander \& P. H. Winne (Eds.), Handbook of educational psychology (2nd ed., pp. 349-367). Mahwah, NJ : Erlbaum. 


\section{Why are social context, interpersonal relationships, and emotional well-being important to student learning?}

\section{PRINCIPLE 13 Learning is situ-} ated within multiple social contexts.

\section{EXPLANATION}

Gifted students are a part of families, peer groups, and classrooms that are situated in larger social contexts of schools, neighborhoods, cultural groups, communities, and society. All of these contexts are influenced by culture, including shared language, beliefs, values, and behavioral norms. Furthermore, these layers of context interact with each other (e.g., schools and families). Research points to the complexity of interactions among learner characteristics and elements of the social environment, and explanations for differences in performance are shifting away from a focus on the learner alone to a focus on the learner in interaction with social and cultural contexts.

It is useful to conceptualize a talent development framework that is embedded within multiple social contexts when considering how gifted students grow and develop their potential into high achievement within a domain. The locus of control for learning in a talent development framework becomes larger than the classroom; it becomes a learning community. Each social context may support or impede a gifted student's precocities. For example, the classroom is just one social context in which learning takes place. Teachers and administrators experience external accountability pressures, such as federal and state mandates, and in many cases these mandates take precedence over what, how much, and when learning occurs in the classroom. Therefore, appreciating the potential influence of each social context on gifted learners can enhance the overall effectiveness of learning.

An ecological theory of talent development for gifted education contends that children exist within a series of settings or contexts -in their families, neighborhoods, schools, supplemental programs, or society.
Further, even though contexts vary, aspects of each influence the child's development, from more proximal influences such as family to more distal influences, such as society. A focus on emergent talent and socially constructed learning offers more opportunity, particularly for low-income and culturally diverse gifted learners, because it allows learning to occur across contexts-home school, and community.

From an educational perspective, low-income high-ability students may often attend schools that do not offer appropriate and frequent intellectual stimulation necessary to encourage talent development. Moreover, because most programs and services for gifted children do not begin before third grade, these students may lose ground in the early years, making early intervention critical.

Research has also shown that psychosocial skills, such as persistence, effort, and self-confidence, are malleable. The deliberate cultivation of psychosocial skills supports high achievement in a domain and is critical to student learning. Psychosocial variables are determining influences in the successful development of talent in a domain. In a comprehensive review of the literature on the social and emotional development of gifted learners, researchers concluded that social- emotional problems that occur in gifted learners usually reflect an interaction between a learner's characteristics and ill-fitting educational contexts that are perceived or experienced by learners as at odds with their needs.

Grouping gifted children is one of the foundations of exemplary gifted education practice, provides access to a peer group, and eases the delivery of appropriately differentiated curriculum to learners with similar educational needs. To meet the academic and social-emotional learning needs of gifted learners, the following should be provided to gifted students at every stage of development: learning situated within multiple social con- 
texts; differentiated educational experiences, including forms of grouping; adjustments in the level, depth, and pacing of curriculum; and outside-of-school programs.

\section{RELEVANCE FOR TEACHERS}

- The more teachers know about the cultural backgrounds of students and how differences in values, beliefs, language, and behavioral expectations can influence student behavior, including interpersonal dynamics, the better they will be able to facilitate effective teaching-learning interactions in their classrooms. For example, for students whose culture is more collectivist than individualistic, teachers can enhance learning experiences through more frequent use of cooperative learning activities.

- Teachers should seek out talent development opportunities for gifted students in and outside of schools. Exposure to local experts in a field can provide a mechanism for mentorships, early exposure to some fields, a model for building expertise, and a learning system that is inclusive of multiple social contexts.

- Teachers and administrators should informally (or formally) assess the social context of their school. For example, do gifted students perceive the school to be competitive, nurturing, anti-intellectual, inclusive of diversity of learning, and so forth? To what degree is the curriculum, instruction, and assessment provided matched to the student? Are there misconceptions about placement of gifted students? Are there policies or practices in place to discourage the advancement of a talent development framework, particularly for low-income, high-ability students?

- Teachers can relate curriculum and instruction to students' cultural backgrounds (e.g., through incorporating local history into social studies lessons or gearing science toward local health problems). Given potential variations in cultural experiences, it is critical that teachers facilitate a "classroom culture" that ensures shared meanings, values, beliefs, and behavioral expectations and provides a safe and secure environment for all students. The use of advanced curriculum in core areas of learning at an accelerated rate has been well document- ed and should be the foundation of any learning for gifted students.

- From a sociocultural perspective, teachers should support students' transfer of their competence to the class and school context in order to capitalize on students' cultural strengths and should encourage them to share their strengths with others. This helps facilitate the transfer from home to school contexts.

- Using a talent development framework implies that at every stage of development, explicit opportunities need to be provided by the school, community, home, region, and so forth, and that the learner engages, takes advantage of, and is committed to those relevant opportunities.

- Decisions about curricular approaches and their implications for classrooms need to be made with a sense of what works for the learner in relevant talent domains, embedded within multiple, interconnected social contexts. This will increase the likelihood of academic performance and help mitigate potential social- emotional issues that may occur between a learner's characteristics and ill-fitting educational contexts.

- American classrooms are becoming increasingly diverse and our world is becoming increasingly interdependent. Having an awareness of one's own cultural identity and the ability to understand and build upon the varying cultural norms in the classroom, community, and society informs and expands the classroom. Cultural competence is a key factor in enabling teachers to be effective with students from cultures other than their own.

- Effective programs and services for gifted students at multiple stages of development have been documented in the literature. ${ }^{7}$ Schools could replicate all or parts of these programs within their own context rather than try to reinvent the wheel.

- Establishing connections with families and local communities can enhance understanding of students' cultural experiences and facilitate shared understandings about learning. Family involve-

\footnotetext{
7 See http:// www.jkcf.org/assets/ 1/ 7/Unlocking_Emergent_Talent. pdf
} 
ment facilitates student learning, so creating opportunities for family and community involvement in the work of the classroom is vital.

- Seeking opportunities to participate at the local community (e.g., attending local cultural events) can help connect the relevance of learning to students' everyday lives and enhance teachers' understanding of the cultural background and experiences of their students.

\section{REFERENCES}

+Brown, E. (2010). Who is the target population for gifted curriculum? In J. VanTassel-Baska \& C. A. Little (Eds.), Content-based curriculum for high ability learners (2nd ed., pp. 33- 47). Waco, TX: Prufrock Press.

+Colangelo, N., Assouline, S., \& Gross, M. (2004). A nation deceived: How schools hold back America's brightest students. Washington, DC: National Association for Gifted Children.

+Cross, T. (1997). Psychological and social aspects of educating gifted students. Peabody J ournal of Education, 72, 180- 200.

+Cross T. L., Coleman L. J ., \& Stewart R. A. (1995). Psychosocial diversity among gifted adolescents: An exploratory study of two groups. Roeper Review, 17, 181- 185.

+Kitano, M. (2003). Gifted potential and poverty: A call for extraordinary action. J ournal for the Education of the Gifted, 26(4), 292- 303.

Lee, P. C., \& Stewart, D. E. (2013). Does a socio-ecological school model promote resilience in primary schools? J ournal of School Health, 83, 795- 804. doi:10.1111/josh.12096

National Association of School Psychologists. (2013). A framework for safe and successful schools. Retrieved from www.nasponline. org

+Neihart, M., Pfeiffer, S., \& Cross, T. (2015). The social and emotional development of gifted children: What do we know? (2nd ed.). Waco, TX: Prufrock Press.

+Olszewski-Kubilius, P., \& Clarenbach, J . (2012). Unlocking emergent talent: Supporting high achievement of low income, high-ability students. Washington, DC: National Association for Gifted Children.

+Olszewski-Kubilius, P., \& Thomson, D. (2015). Talent development as a framework for gifted education. Gifted Child Today, 38, 49- 59.

+Plucker, J . A., Hardesty, J ., \& Burroughs, N. (2013). Talent on the sidelines: Excellence gaps and America's persistent talent underclass. Storrs, CT: University of Connecticut, Center for Education Policy Analysis.

+Rogers, K. B. (2002). Re-forming gifted education: Matching the program to the child. Scottsdale, AZ: Great Potential Press.

Rogoff, B. (2003). The cultural nature of human development. New York: Oxford University Press.
+Subotnik, R., Olszewski-Kubilius, P., \&Worrell, F. ( 2011). Rethinking giftedness and gifted education: A proposed direction forward based on psychological science. Psychological Science in the Public Interest, 12, 3- 54.

Thapa, A., Cohen, J., Higgins-D’Alessandro, \& Gaffey, S. (2012). School climate research summary: August 2012. New York, NY: National School Climate Center.

Trickett, E. J ., \& Rowe, H. L. (2012). Emerging ecological approaches to prevention, health promotion, and public health in the school context: Next steps from a community psychology perspective. J ournal of Educational and Psychological Consultation, 22, 125- 140. doi:10.1080/ 10474412.2011.649651

+VanTassel-Baska, J ., \& Brown, E. (2007). Toward best practice: An analysis of the efficacy of curriculum models in gifted education. Gifted Child Quarterly, 51, 342- 358.

+VanTassel-Baska, J ., \& Stambaugh, T. (2007). Overlooked gems: A national perspective on low income promising learners. Washington, DC: National Association for Gifted Children.

Ysseldyke, J ., Lekwa, A. J ., Klingbeil, D. A., \& Cormier, D. C. (2012). Assessment of ecological factors as an integral part of academic and mental health consultation. J ournal of Educational and Psychological Consultation, 22, 21-43. doi:10.1080/ 10474412. 2011.649641

\section{PRINCIPLE 14 Interpersonal re-} lationships and interpersonal communication are critical to both the teaching-learning process and the social development of students.

\section{EXPLANATION}

The teaching-learning process in preK- 12 classrooms is inherently interpersonal, encompassing both teacher-student and peer connections. These relationships are critical not only to an effective teaching- learning process but also to establishing successful peer and adult relationships and facilitating the healthy social-emotional development of students. Given the social nature of classrooms, these contexts provide a critical context for teaching social skills such as communication, respect for others, and establishing and maintaining healthy relationships. Developing successful relationships with peers and adults is highly dependent on one's ability to communicate thoughts and feelings through verbal and nonverbal behavior. ${ }^{8}$

${ }^{8}$ See also http:/ / www.apa.org/ education/k12/ relationships.aspx 
Social comparisons can inhibit the development of interpersonal relations. When students are frequently outperformed by a gifted peer, they may feel negatively about their own abilities and avoid interacting with him or her. Students with exceptional abilities who often perform better than peers may become concerned about being the target of such upward comparisons. Strategies to avoid stigmatization as a gifted student may be positive (e.g., helping peers, engaging in extracurricular activities) or negative (e.g., denying one's exceptional abilities, intentionally underachieving). Peer tutoring offers the potential to encourage positive interpersonal relations but can be detrimental if the tutee is humiliated by the process or if the tutor feels exploited by it.

The social status of academically oriented students tends to be low in secondary schools, at least in the United States, discouraging identification as a high achiever. Feeling unappreciated, misunderstood, or taken advantage of may lead gifted students to prefer working alone over working with peers. The ability to communicate may come easily to verbally gifted students, but research suggests they may be more vulnerable to peer rejection, perhaps because their cognitive differences are readily apparent through their speech. Teachers who create a classroom norm of appreciation for all forms of diversity, including linguistic and cognitive diversity, with an emphasis on cooperation over competitiveness, will foster interpersonal relationships among all students, including their gifted students.

\section{RELEVANCE FOR TEACHERS}

Given the interpersonal nature of preK- 12 teaching and learning, teachers can attend to the relational aspects of the classroom:

- A safe and secure environment, both physical and social, and shared classroom culture (e.g., ensuring that everyone in the classroom is clear about relevant vocabulary, values, and norms) provide the foundation for healthy teacher-student and peer relationships.
- Emotionally supportive teachers who ensure appropriately rigorous lessons for all students set the stage for the development of positive interpersonal relationships.

- Social comparisons can be minimized by strategically emphasizing cooperative learning activities to decrease attention to differences of ability among students. When competitive learning activities are used, they can be focused on self-improvement or team efforts rather than on winning or on winner take all.

- Teachers should avoid referring to the academic hierarchy in a class, as this creates a negative environment for interpersonal relations. Holding gifted students up as examples for peers makes them the target of upward comparisons.

- Teachers can help gifted students fit in with peers by encouraging positive social strategies that do not result in lowered achievement.

- Group work should be carefully monitored to ensure all members are contributing appropriately.

- Peer tutoring should be offered as a voluntary activity for students who express a desire to help or be helped.

- Teachers can provide clear behavioral expectations related to social interactions (e.g., respect for others, use of clear communication, nonviolent conflict resolution) and provide opportunities for all students to experience successful social exchanges.

- Not only can teachers establish cooperative and supportive classroom norms, but it is also critical that teachers set clear injunctions against bullying in any form.

- Opportunities to learn effective social skills should include planned instruction and opportunities for practice and feedback. Critical social skills include cooperation/ collaboration, perspective taking and seeking, respect for others' views, providing constructive feedback, interpersonal problem solving, and conflict resolution. 
- Teachers have a responsibility to ensure that a positive social climate is maintained, student conflicts are resolved peacefully, and early intervention takes place should bullying occur.

One of the foundational skills for the more complex interactions described above is the development of clear and thoughtful communication. Effective student communication requires teaching and practice of component skills. Teachers may incorporate lessons in communication basics as part of the routine curriculum. For example, they might incorporate specific skills into a lesson (such as how to ask relevant questions) and provide opportunities to apply those skills, such as during cooperative learning. In addition, teachers can:

- $\quad$ Prompt students to:

- elaborate on their responses,

- engage in respectful give and take with other students during discussions,

- seek clarification from others,

- listen carefully to others, and

- read nonverbal cues.

- Provide opportunities for students to practice communication in both academic and social contexts.

- Foster the ability of verbally gifted students to recognize and reflect others' speech patterns in varied social contexts.

- Provide feedback to enhance skill development.

Furthermore, teachers can model effective verbal and nonverbal communication by using active listening, matching facial expression with verbal messages, using questions effectively, providing elaboration in response to student questions, and seeking student perspectives.

\section{REFERENCES}

Centers for Disease Control and Prevention. (2009). School connectedness: Strategies for increasing protective factors among youth. Retrieved from http:// www.cdc.gov/ healthyyouth/ protective/ pdf/ connectedness.pdf

+Coleman, L. J ., \& Cross, T. L. (1988). Is being gifted a social handicap? J ournal for the Education of the Gifted, 11, 41- 56.

+Cross, J . R. (2015). Peer relationships of gifted children. In M. Neihart, S. Pfeiffer, \& T. L. Cross (Eds.), Social and emotional development of gifted children (2nd ed., pp. 41-54). Washington, DC: National Association for Gifted Children.

+Cross, J . R., Bugaj, S. J ., \& Mammadov, S. (2016). Accepting a scholarly identity: Gifted students, academic crowd membership, and identification with school. J ournal for the Education of the Gifted, 39, 23-48. doi:10.1177/0162353215624162

Durlak, J ., Dymnicki, A., Taylor, R., Schellinger, K. \& Weissberg, R. (2011). The impact of enhancing students' social and emotional learning: A meta-analysis of school-based universal interventions. Child Development, 82, 405-432. doi:10.1111/j.14678624.2010.01564.x

+French, L. R., Walker, C. L., \& Shore, B. M. (2011). Do gifted students really prefer to work alone? Roeper Review, 33, 145- 159.

+Lee, S.-Y., Olszewski-Kubilius, P., \&Thomson, D. T. (2012). Academically gifted students' perceived interpersonal competence and peer relationships. Gifted Child Quarterly, 56, 90- 104.

Pianta, R. C., \& Stuhlman, M. W. (2004). Teacher-child relationships and children's success in the first years of school. School Psychology Review, 33, 444- 458.

Rimm-Kaufman, S. E., Baroody, A. E., Larsen, R. A. A., Curby, T. W., \&Abry, T. (2015). To what extent do teacher- student interaction quality and student gender contribute to fifth graders' engagement in mathematics learning? J ournal of Educational Psychology, 107, 170-185. doi:10.1037/a0037252

Webster-Stratton, C., Reinke, W. M., Herman, K. C., \&Newcomer, L. L. (2013). The Incredible Years teacher classroom management training: The methods and principles that support fidelity of training delivery. School Psychology Review, 40, 509- 529.

+Worrell, F. C., Knotek, S. E., Plucker, J . A., Portenga, S., Simonton, D. K., Olszewski-Kubilius, P., . . Subotnik, R. F. (2016). Competition's role in developing psychological strength and outstanding performance. Review of General Psychology, 20, 259- 271. doi:10.1037/gpr0000079 
PRINCIPLE 15 Emotional

\author{
well-being influences educational \\ performance, learning, and devel- \\ opment.
}

\section{EXPLANATION}

Emotional well-being is integral to successful, everyday functioning in the classroom and influences academic performance and learning. It is also important to interpersonal relationships, social development, and overall mental health. The components of emotional well-being include sense of self (self-concept, self-esteem), a sense of control over oneself and one's environment (self-efficacy, locus of control), general feelings of well-being (happiness, contentment, calm), and capacity for responding in healthy ways to everyday stresses (coping skills). Being emotionally healthy depends on understanding, expressing, and regulating or controlling one's own emotions, as well as perceiving and understanding others' emotions (empathy). Understanding others' emotions is influenced by how students perceive external expectations and acceptance on the part of significant others in their classroom, family, peer group, community, and societal environment (see Principles 13 and 14).

Gifted children experience the same social and emotional needs as other children, but they also face some unique psychological issues. As a group, they are generally well-adjusted, but they sometimes require support or intervention to help them cope with peer relations, uneven development, perfectionism, or challenges to self-esteem. They generally have good academic self-concepts but may struggle, especially when placed in classrooms that are competitive or have either a great deal or too little challenge. Overall, gifted children tend to be more similar socially and emotionally to older children than to same-age peers because psychosocial maturity is tied more closely to mental age than to chronological age. Therefore, for many gifted students, though not all, some form of academic acceleration can provide a better fit for social and cognitive match with peers.

Research suggests that adults are often not aware of gifted students' psychological distress nor of the factors that contribute to their burdens because the students tend to maintain high achievement even when distressed. College admission processes, high-stakes assessments, difficult courses, transitions, and complex projects are typical sources of tension for these students. They may be gifted in many areas and exhibit strong interest across multiple domains, which can contribute to overcommitment.

Approximately 20-30\% of gifted students have self-critical, evaluative concerns that cause them anxiety. Twice-exceptional children in particular often have more emotional difficulties in school due to frustrations arising from extreme differences in their abilities. Similarly, gifted children with the highest abilities may struggle with social self-esteem, loneliness, and isolation despite their exceptional ability, due to the great differences between their own interests and abilities and those of their age mates, especially in situations where services are not available or provided.

\section{RELEVANCE FOR TEACHERS}

Gifted students' emotional well-being influences the quality of their participation in the teaching- learning process. It can affect their interpersonal relationships, the effectiveness of their communication, their motivation, and their engagement. The teacher is key to establishing a classroom climate in which all students are accepted, valued, and respected; have opportunities to achieve at a level of challenge appropriate to their abilities; and have opportunities for positive social relationships with adults and peers. Teachers can help facilitate gifted students' emotional well-being in the following ways:

- Remember that as a group, gifted children are generally well-adjusted, but they sometimes require support or intervention to help them cope with peer relations, uneven development, perfectionism, or challenges to self-esteem.

- Acknowledge that all gifted children do not have the same emotional needs. The emotional needs of twice-exceptional children in particular are likely to be more pronounced.

- Remember that grades and achievement behavior are not reliable indicators of gifted students' stress levels or coping, as they are often able to maintain 
high achievement even in the face of considerable psychological distress

- Occasionally inquire about students' feelings and how they are managing higher stress periods in the academic year.

- Help gifted children who struggle with overly critical, self-evaluative concerns to reframe their expectations.

- Monitor students who are achieving at very high levels in multiple domains. These students may feel overextended, pressured, and burdened by the heavy expectations from themselves and adults.

- Explicitly teach emotion regulation strategies such as "stop and think before acting," diaphragmatic breathing, and progressive relaxation. Incorporating these strategies into daily classroom routines and reminding students to use them when faced with higher stress situations can go a long way to helping them internalize these tools.

- Explicitly teach students mental skills training to help them manage focus, anxiety, challenge, and stress.

- Monitor the level of challenge in the curriculum so that the most capable students are not bored with work that is too easy.

- Be careful about encouraging ultra-competitive attitudes or classrooms. These can add to students' stress and unhappiness.

- Model emotional understanding of others, such as empathy and compassion.

- Provide a menu of interventions and supports to develop emotional health.

- Do not enable students to avoid circumstances that cause them stress, but gently move them to approach their fears while using the coping strategies they have been taught.

- Emphasize the value of seeking positive emotional experiences in response to stressors, especially humor.
- Accept the strong empirical evidence that one of the most effective school-based interventions for meeting the needs of gifted children is academic acceleration. This can take many forms, including grade skipping, early entrance to college, and various forms of subject acceleration.

\section{REFERENCES}

+Assouline, S. G., Foley Nicpon, M., \&Whiteman, C. (2010). Cognitive and psychosocial characteristics of gifted students with specific learning disabilities. Gifted Child Quarterly, 54, 102- 115.

CASEL (Collaborative for Academic, Social, and Emotional Learning). (2012). CASEL Guide: Effective social and emotional learning programs (Preschool and elementary school ed.). Retrieved from www.casel.org

+Delcourt, M. A. B., Cornell, D. G., \& Goldberg, M. D. (2007). Cognitive and affective learning outcomes of gifted elementary school students. Gifted Child Quarterly, 51, 359- 381. doi:10.1177/0016986207306320

+Ecklund, K., Tanner, N., Stoll, K., \&Anway, L. (2015). Identifying emotional and behavioral risk among gifted and non-gifted children: A multi-gate, multi-informant approach. School Psychology Quarterly, 30, 197- 211.

+Foley Nicpon, M., Allman, A., Sieck, B., \& Stinson, R. D. (2011). Empirical investigation of twice exceptionality: Where have we been and where are we going? Gifted Child Quarterly, 55, 3- 17.

+Foley Nicpon, M., Doobay, A., \& Assouline, S. G. (2010). Teacher, parent, and self-perceptions of psychosocial functioning in intellectually gifted children and adolescents with autism spectrum disorder. J ournal of Autism and Developmental Disabilities, 40, 1028- 1038.

+Gross, M.U. M. (2004). Exceptionally gifted children (2nd ed.). London, UK: Routledge Falmer.

Hagelskamp, C., Brackett, M. A., Rivers, S. E., \& Salovey, P. (2013). Improving classroom quality with the RULER approach to social and emotional learning: Proximal and distal outcomes. American J ournal of Community Psychology, 51, 530- 543. doi:10.1007/s10464-013-9570-x

J ones, S. M., Brown, J . L., \&Aber, J . L. (2011). Two-year impacts of a universal school-based social-emotional and literacy intervention: An experiment in translational developmental research. Child Development, 82, 533- 554. doi:10.1111/j.14678624.2010.01560.x

+Rogers, K. (2010). Academic acceleration and giftedness: The research from 1990-2008, a best evidence synthesis. In Proceedings of the acceleration poster session at the 2008 Wallace Research Symposium on Talent Development. Retrieved from http:// www.accelerationinstitute.org/proceedings_2008.pdf

Seligman, M.E.P., Ernst, R. M., Gillham, J ., Reivich, K., \&Linkins, M. (2009). Positive education: Positive psychology and classroom interventions. Oxford Review of Education, 35, 293- 311.

+Shaunessy, E., \& Suldo, S. M. (2010). Strategies used by intellectually gifted students to cope with stress during their participation in a high school international baccalaureate program. Gifted Child Quarterly, 54, 127- 137. doi:10.1177/0016986209355977 


\section{How can the classroom best be managed?}

PRINCIPLE 16 Expectations for classroom conduct and social interaction are learned and can be taught using proven principles of behavior and effective classroom instruction.

\section{EXPLANATION}

Students' ability to learn is as much affected by their interpersonal and intrapersonal behavior as it is by their academic skills. Student behavior that does not conform to classroom rules or teacher expectations cannot simply be regarded as a distraction to be eliminated before instruction can take place. Rather, behaviors conducive to learning and appropriate social interaction are best taught at the beginning of the academic year and reinforced throughout the year. These behaviors can be taught using proven behavioral principles. For students exhibiting more serious or consistent problem behaviors, understanding the context and function of the behavior is a key element in teaching appropriate replacement behaviors. ${ }^{9}$

Gifted students can be advanced in different academic areas, but like nongifted students, they may demonstrate challenging behaviors within classrooms and often for similar reasons. Some issues unique to gifted children that may affect their classroom behavior include being academically gifted but experiencing social-emotional difficulties, being twice-exceptional with learning or behavior disabilities, being culturally or linguistically different, being creative beyond the conventional learning process, or being bored in classrooms lacking challenge and inspiration. Educators need to be aware of students' unique backgrounds,

9 See also http:// www.apa.org/ education/k12/ classroom-mgmt.aspx and http:// www.apa.org/ ed/schools/ cpse/ activities/ class-management.aspx their ability levels, and their individual strengths and weaknesses. Teachers are expected to implement specific classroom management strategies and differentiated instructions so as to provide gifted students with a favorable learning environment and suitable subject matter.

\section{RELEVANCE FOR TEACHERS}

A common assumption is that instruction is only intended for those who are "ready to learn" and that the learning environment will be improved if those who disrupt or distract from it are removed.

- Regular classroom teachers need to be aware that there are gifted students in the regular classroom, and it is the teachers' responsibility to create a challenging and yet safe and encouraging learning environment appropriate to gifted students' development.

- The classroom behavior and social interaction of gifted students can be similar to those of regular students, and it is important for educators to establish clear expectations and rules at the beginning of the school year. A range of behavioral principles, including praise for appropriate behavior, differential reinforcement (desired behaviors or responses are reinforced and inappropriate behaviors or responses are ignored), correction, and planned consequences can be used to consistently teach and remind students of their expectations.

- One critical element of an effective classroom is appropriate implementation of differentiated and accelerated instruction. Differentiation with a variety of strategies will not only provide gifted students sufficient learning opportunities but also reduce potential behavioral problems within the classroom that may occur due to boredom, limited learning, or lack of stimulation. Gifted students often possess an intense desire to learn about their 
own interests, and the teaching content, process, and product need to consider differentiated and accelerated strategies to meet their special needs.

- To recruit and retain culturally different students in gifted education, all classrooms need to be culturally responsive to students from diverse backgrounds. Classroom environment can have powerful impact on gifted students, influencing their motivation, engagement, and sense of belonging. Gifted minority students will feel valued and welcomed in culturally responsive classrooms and school environments and will display resilience when challenged by outside factors.

- Gifted students may exhibit antisocial behavior, withdraw from classroom interaction, or underachieve in classrooms that are not differentiated properly or when the instructional pace is not accelerated to match their learning rate. It is important for adults not to assume these behaviors are associated with giftedness. Rather, they may result from mismatched environments. Using appropriate differentiation strategies in teaching can provide gifted students with more desirable learning opportunities, resulting in better classroom behavior and more positive learning outcomes.

\section{REFERENCES}

American Psychological Association, Zero Tolerance Task Force. (2008). Are zero tolerance policies effective in the schools? An evidentiary review and recommendations. American Psychologist, 63, 852- 862. doi:10.1037/ 0003-066X.63.9.852

+Boor-Klip, H. J ., Cillessen, A. H. N., \&Hell, J . G. (2014). Social understanding of high-ability children in middle and late childhood. Gifted Child Quarterly, 58, 259- 271.

+Coleman, L. J., Micko, K. J., \& Cross, T. L. (2015). Twenty-five years of research on the lived experience of being gifted in school: Capturing the students' voices. J ournal for the Education of the Gifted, 38, 358- 376.

Evertson, C. M., \&Emmer, E. T. (2009). Classroom management for elementary teachers (8th ed.). Upper Saddle River, NJ : Pearson.

+Ford, D. Y. (2015). Culturally responsive gifted classrooms for culturally different students: A focus on invitational learning. Gifted Child Today, 38, 67- 69.

+Gentry, M., Paul, K. S., McIntosh, J., Fugate, M., \&J en, E. (2014). Total school cluster grouping \& differentiation: A comprehensive, research-based plan for raising student achievement and improving teacher practice (2nd ed.). Waco, TX: Prufrock Press.
+Manning, S. (2006). Recognizing gifted students: A practical guide for teachers. Kappa Delta Pi Record, 42, 64- 68.

Skiba, R., \& Peterson, R. (2003). Teaching the social curriculum: School discipline as instruction. Preventing School Failure, 47, 66- 73.

Slavin, R. E. (Ed.). (2014). Classroom management and assessment. Thousand Oaks, CA: Corwin Press.

Sprick, R. (2006). Discipline in the secondary classroom: A positive approach to behavior management (2nd ed.). San Francisco, CA: J ossey-Bass.

Sugai, G., \& Simonsen, B. (2015). Supporting general classroom management: Tier 2/ 3 practices and systems. In E. T. Emmer \&E. J. Sabornie (Eds.), Handbook of classroom management (2nd ed.). New York, NY: Taylor \& Francis.

+Tomlinson, C. A., Kaplan, S. N., Renzulli, J . S., Purcell, J ., Leppien, J., Burns, D. E., . . Imbeau, M. B. (2008). The parallel curriculum: A design to develop high potential and challenge high-ability learners (2nd ed). Thousand Oaks, CA: Corwin Press.

+Wu, E. H. (2013). The path leading to differentiation: An interview with Carol Tomlinson. J ournal of Advanced Academics, 24, 125- 133.

PRINCIPLE 17 Effective classroom management is based on (a) setting and communicating high expectations, (b) consistently nurturing positive relationships, and (c) providing a high level of student support.

\section{EXPLANATION}

At both the classroom and school level, the development of an effective learning climate is based in both structure and support. Many schools and teachers are facing more diverse groups of students who may need not only academic support but also social- emotional and psychological support from teachers and school communities. In terms of structure, students need to have a clear understanding of the behavioral rules and expectations of the classroom; these expectations must be communicated directly and frequently and must be consistently enforced. Yet we also know that support is essential. To be both effective and culturally responsive, teachers can develop and maintain strong, positive relationships with their students by consis- 
tently communicating that they are firmly committed to supporting all of their students in meeting those high academic and behavioral expectations.

\section{RELEVANCE FOR TEACHERS}

Students profit from a predictable structure and high expectations for both academic achievement and classroom behavior. For example:

- Gifted students benefit from high expectations, predicable classroom schedules, clear guidance, consistently enforced rules, and well-organized procedures for learning activities. Such rules and procedures can be taught and retaught so that students understand clearly what the desired and undesired behaviors are and what they are expected to do. Teachers' consistent implementation of these rules and their timely, specific communication of feedback are also vital in helping gifted students experience meaningful classroom learning.

- The most effective teachers, schools, and programs also emphasize the development of supportive and nurturing relationships with students (see Principle 15). Teachers need to create a safe and optimal learning environment with positive teacher-student and peer relationships. Such a learning environment can provide gifted students with opportunities to take risks and challenge themselves, helping them achieve at a high level and fulfill their potential.

- Teachers need to focus more on positive rather than negative behaviors of students, maintaining a high ratio of positive statements, and to build mutual trust respect between student and teacher. Clear indications of expectations for student cooperation and the use of positive verbal and nonverbal communication can also help increase students' sense of responsibility, as well as their independence and self-discipline.

- Effective classroom management also needs high levels of support for students, including academic as well as social-emotional and psychological support. Research indicates that there is a positive correlation between poor social- emotional development and scholastic underachievement in gifted students. Promoting students' academic achieve- ments as well as supporting their social- emotional needs will help promote gifted students' well-being.

- Teachers' professional knowledge and advanced preparations, as well as their understanding of individual differences and students' individual needs, are critical in working with gifted students. Teachers' encouragement of peer acceptance and their awareness of gifted students' potential social and emotional vulnerabilities can help prevent behavioral problems and underachievement and maintain a positive classroom environment for gifted students.

- Teachers should create classroom environments that value responsibility and collaboration. Support from teachers, schools, parents, and the community can better serve the needs of the gifted by stimulating their interests, passions, and motivation for learning and achieving.

\section{REFERENCES}

+Blaas, S. (2014). The relationship between social-emotional difficulties and underachievement of gifted students. Australian J ournal of Guidance \& Counselling, 24, 243- 255.

+Canter, L. (2009). Assertive discipline: Positive behavior management for today's classroom. Bloomington, IN: Solution Tree Press.

Evertson, C. M., \&Emmer, E. T. (2009). Classroom management for elementary teachers (8th ed.). Upper Saddle River, NJ : Pearson.

+Hébert, T. P. (2011). Understanding the social and emotional lives of gifted students. Waco, TX: Prufrock Press.

+J ones, V., \&J ones, L. (2010). Comprehensive classroom management: Creating communities of support and solving problems. Upper Saddle River, NJ : Merrill.

+Rogers, B. (2015). Classroom behavior: A practical guide to effective teaching, behavior management colleague support. Thousand Oaks, CA: Sage.

Rothstein-Fisch, C., \& Trumball, E. (2008). Managing diverse classrooms: How to build on students' cultural strengths. Alexandria, VA: Association for Supervision and Curriculum Development.

Skiba, R., \& Peterson, R. (2003). Teaching the social curriculum: School discipline as instruction. Preventing School Failure, 47, 66- 73.

+VanTassel-Baska, J ., \& Stambaugh, T. (2005). Challenges and possibilities for serving gifted learners in the regular classroom. Theory Into Practice, 44, 211- 217.

Weinstein, C., Tomlinson-Clarke, S., \& Curran, M. (2004). Toward a conception of culturally responsive classroom management. J ournal of Teacher Education 55, 25- 38. 


\section{PRINCIPLE 18 Formative and} summative assessments are both important and useful but require different approaches and interpretations.

\section{EXPLANATION}

Formative assessments provide information about gifted students that is useful in making decisions about curriculum, instructional strategies, grouping, and acceleration. Summative assessments are useful in evaluating gifted students' learning progress, the effectiveness of curricular and instructional practices, and the overall educational program.

Because learning experiences should be matched to the strengths and needs of gifted students, formative assessments that take place prior to instruction are used to determine readiness levels and to eliminate the need for students to repeat material that has already been learned, allowing them to pursue advanced content and individual interests. Formative assessments that take place during instruction enhance learning progress by producing data that can provide the teacher with information about each student's gaps in knowledge and skills, interests and strengths, need for personalized pacing, and placement in a like-performing group. Summative assessments measure learning at a particular point, usually at the end of a unit of study, semester, or academic year and by design provide limited opportunities to influence current learning activities. Nevertheless, they are useful in evaluating the effects of curricular and instructional practices on learner progress.

The approach used to collect information is likely to differ between the two types of assessment as well, given their different purposes. Formative assess-

\section{How to assess student progress?}

ments used to enhance gifted learners' progress are more likely to focus on big ideas or concepts, problem solving, critical and creative thinking, and above-level content so that students are able to show the extent of what they know and do not know. To assess more complex concepts and higher level thinking, performance-based or authentic tasks are often used, involving projects, demonstrations, debates, scenario-based problem solving, and other types of open-ended tasks. Optimally, the teacher and the student collaborate and use specific assessment criteria to determine progress.

Summative assessments, the purpose of which is to help teachers evaluate student progress and program effectiveness, may include end-of-semester exams, auditions, product exhibits, a portfolio review, benchmark tests, and criterion- or norm-referenced, standardized state tests, which can be used to yield an overall score or performance-level designation for the school.

Both formative and summative assessments can be developed by teachers or those outside of the classroom-for example, by a testing company on behalf of a state agency. In general, however, formative assessments are more likely to be developed by teachers, and large-scale, high-stakes assessments are more likely to be developed by an external organization. Overall, the goal of both types of assessments is fundamentally the same - to produce valid, fair, useful, and reliable sources of information.

\section{RELEVANCE FOR TEACHERS}

Using formative assessments can result in important increases in student learning when teachers:

- Clearly communicate and involve gifted students in the purposes of each lesson and in assessing the quality of their own learning. 
- Use lessons and other classroom experiences to monitor and collect evidence on gifted students' learning.

- Use this evidence to help understand what gifted students know and adjust plans, enriching and accelerating learning as appropriate.

Teachers can improve the effectiveness of formative assessments when they:

- Align the assessments with appropriate learning goals for gifted students.

- Use authentic, above-level, and differentiated assessments to identify what gifted and advanced students know and don't know.

- Develop long- and short-range goals based on multiple types of assessments that consider each gifted student's abilities, achievement levels, needs, and interests.

- Engage gifted students in determining whether they have met these goals.

- Use formative assessment continually to adjust curriculum and pace instruction based on the learning capabilities of gifted and advanced students.

Teachers can make better use of both formative and summative assessments when they understand basic concepts related to educational measurement. They need to use this knowledge to differentiate assessments and interpret results to guide educational decisions. Teachers can also use assessment data to evaluate their own instruction to consider whether each student is making adequate progress according to their abilities and needs.

\section{REFERENCES}

Black, P., Harrison, C., Lee, C., Marshall, B., \&Wiliam, D. (2003). Assessment for learning: Putting it into practice. Buckingham, England: Open University Press.

Council of Chief State School Officers (CCSSO). (2008). Formative assessment: Examples of practice. Retrieved from the CCSSO website: http:// ccsso.org/ Documents/2008/ Formative_Assessment_Examples_2008.pdf
Heritage, M. (2007). Formative assessment: What do teachers need to know and do? Phi Delta Kappan, 89, 140- 145.

+Moon, T. R., Brighton, C. M., Callahan, C. M., \& Robinson, A. (2005). Development of authentic assessments for the middle school classroom. J ournal of Secondary Gifted Education, 2/ 3, 119- 133.

+Rambo-Hernandez, K. E., \&Warne, R. T. (2015). Measuring the outliers: An introduction to out-of-level testing with high-achieving students. Teaching Exceptional Children, 47, 199- 207.

Sheppard, L. A. (2006). Classroom assessment. In R. L. Brennan (Eds.), Educational measurement (4th ed., pp. 623- 646). Westport, CT: American Council on Education/ Praeger.

+Thomson, D., \& Olszewski-Kubilius, P. (2014). The increasingly important role of off-level testing in the context of the talent development perspective. Gifted Child Today, 37(1), 33- 40.

+VanTassel-Baska, J . (Ed.). (2008). Alternative assessments with gifted and talented students. Waco, TX: Prufrock Press.

+Warne, R. T. (2012). History and development of above-level testing of the gifted. Roeper Review, 34, 183- 193.

Wylie, C., \&Lyon, C. (2012, J une). Formative assessment-Supporting students' learning. R \& D Connections (No. 19). Retrieved from the Educational Testing Service website: http:/ / www.ets. org/ Media/ Research/pdf/RD_Connections_19.pdf

PRINCIPLE 19 Students' skills, knowledge, and abilities are best measured with assessment processes grounded in psychological science with well-defined standards for quality and fairness.

\section{EXPLANATION}

PreK- 12 teachers and leaders are working in an era in which assessments are a constant topic of discussion and debate. It is important to remember, however, that there are clear standards for judging the quality of assessments of any type. This is true of both formative and summative assessment (see the Standards for Educational and Psychological Testing, AERA, APA, \& NCME, 2014). Assessments that are both reliable and valid help test score users make appropriate inferences about students' knowledge, skills, and abilities. 
The validity of an assessment can be thought of in relation to four essential questions:

- How much of what you want to measure is actually being measured?

- How much of what you did not intend to measure is actually being measured?

- What are the intended and unintended consequences of the assessment?

- What evidence do you have to support your answers to the first three questions?

The validity of an assessment tool is not simply a number. It is a body of evidence, built over time and across a variety of situations, about the inferences that can be drawn from test data. Such evidence is gathered by examining the content of the test and the content's representation of the area (e.g., math achievement) being measured and by examining how the test scores relate (or not) to other measures. For example, test users need to be able to make inferences from a test score that accurately reflect student learning in mathematics and not other factors.

Fairness is also a component of validity. Valid assessment requires saying clearly what an assessment is and is not supposed to measure and requires evidence of this for all test takers. Tests that show real, relevant differences are fair; tests that show differences that are unrelated to the purpose of the test are not.

Reliability of an assessment is another key factor. An assessment's scores are considered reliable when they are free from random measurement error and are consistent from one testing occasion to another. Scores should not be affected by chance factors associated with, for example, student motivation or interest as it relates to a given set of test questions, variations in testing conditions, or other things that are not part of what test users intend to measure.

In a gifted education setting, evidence about an assessment's validity is particularly noteworthy because of the consequences associated with an assessment's outcome (e.g., consideration of ethical and equity issues involved with the labeling of children as "gifted" or "not gifted" and the educational and social opportunities afforded because of the label). Consequently, a test user would want sufficient evidence of an assessment's validity in order to use the assessment for gifted programming. Furthermore, in the identification process, because there is little agreement on a unifying definition of giftedness and because giftedness is affected by previous educational opportunity and context, it is imperative that test users base their judgments regarding the validity of an assessment on the degree to which it matches explicit and detailed criteria that define "gifted" for a particular context, content area, group of learners, and stage of development.

\section{RELEVANCE FOR TEACHERS}

The assessment of student learning is strongly influenced by a teacher's understanding and interpretation of assessment results and the action taken as a result. Whenever teachers give an assessment for classroom purposes, it is best to consider its strengths and limitations with respect to what they hope it will tell them about their students' learning. Teachers can apply strategies to improve the reliability of their assessments and be cognizant of why some assessments will be more reliable than others. Ways in which teachers can improve the quality of the assessments they use in their classrooms include:

- Being mindful that assessments should be used for the specific purpose for which were developed.

- Carefully aligning assessments with what is taught, which can be done through mapping an assessment's coverage in comparison to instructional time or emphases as represented in lesson plans.

- Using a sufficient number of questions overall and a variety of question types (e.g., multiple-choice and constructed response) that allow for the full range of student responses and mastery beyond grade level.

- Using item analysis to minimize bias. For example, teachers can easily check the relative difficulty of questions (i.e., too hard or too easy) in general to ensure there is not a ceiling for gifted learners and also with regard to student subpopulations (e.g., native speakers compared with English language learners). 
- Basing important decisions on multiple measures instead of a single assessment.

\section{REFERENCES}

American Educational Research Association, American Psychological Association, \& National Council on Measurement in Education. (2014). Standards for educational and psychological testing. Washington, DC: American Educational Research Association.

Brookhart, S. (2011). Educational assessment knowledge and skills for teachers. Educational Measurement: Issues and Practice, 30(1), 3- 12.

+Cowie, B., \& Harrison, C. (2016). Classroom processes that support effective assessment. In G. T. L. Brown \& L. R. Harris (Eds.), Handbook of human and social conditions in assessment (pp. 335- 350). New York, NY: Routledge.

McMillan, J . H. (2000). Fundamental assessment principles for teachers and school administrators. Practical Assessment, Research \& Evaluation, 7(8). Retrieved from http:// pareonline. net/ getvn.asp?v=7\&n=8

Moss, P. A. (2003). Reconceptualizing validity for classroom assessment. Educational Measurement: Issues and Practice, 22, 13- 25.

Smith, J. K. (2003). Reconsidering reliability in classroom assessment and grading. Educational Measurement: Issues and Practice, 22, 26- 33.

\section{PRINCIPLE 20 Making sense of} assessment data depends on clear, appropriate, and fair interpretation.

\section{EXPLANATION}

The meaning of assessment outcomes depends upon clear, appropriate, and fair interpretation. Scores from any assessment should generally be used only for the specific purposes for which the assessments were designed. For example, tests that are intended to rank order students for a competition may be valid, fair, and useful for that purpose but would likely be misleading for determining the strengths and weaknesses of each individual student's mastery of material in a particular subject-matter area.

In a gifted education setting, assessment data generally result from four different sources: (a) data from identification processes and procedures; (b) data from accountability systems (e.g., state, program); (c) data from gifted program evaluations; and/ or (d) data from classroom settings. It is important to consider the potential pitfalls of each. For example, data from identification processes and state accountability systems are typically limited in their usefulness in planning the curriculum for gifted learners because of ceiling effects, the lack of content specificity in the case of identification data, or the challenges associated with accurately assessing cultural and linguistically diverse gifted students. Data obtained from classroom assessments may be more directly tied to curriculum and instructional planning but are in general limited because the assessments have not been constructed with the same level of quality control as external assessments (e.g., state assessments). However, regardless of the source, appropriate and fair interpretations of data require a full understanding of how different factors (e.g., educational or personal backgrounds) influence the nature of an assessment and student outcomes and thus, potentially, interpretations.

Within the field of gifted education, many are beginning to use secondary data analysis from large-scale longitudinal data sets collected by governmental and other agencies (e.g., Add Health data collected by the National Institute of Child Health and Human Development) to understand relationships among a variety of variables that involve gifted students. For example, the Add Health dataset has been used to explore protective factors against depression in adolescent gifted students, where gifted was defined by the top $5 \%$ of scores on the Add Health Picture Vocabulary Test.

It is important to realize that care must be taken when interpreting results from these types of analyses, as in the vast majority of instances, gifted is often defined by proxies within the data sets rather than direct measures of giftedness (e.g., combining multiple variables to create a proxy for gifted or some other variable[s] serving as surrogates for giftedness, such as grade point average).

\section{RELEVANCE FOR TEACHERS}

Advances in cognitive psychology have deepened our understanding of how students learn. Consequently, our assessment modalities (the ways we assess students) have broadened how we acquire evidence about students' developing knowledge. Regardless of where the data originate, it is important to understand that 
data interpretation is not an end but rather a means to improve decisions about instructional methods (or programs). To provide appropriate and fair interpretations of student data, teachers must recognize that all assessments contain error (i.e., are imprecise) and thus provide incomplete evidence about student performance; therefore, assessments should be combined with other sources of evidence for making important decisions. Furthermore, when working with gifted students, teachers should use assessments that allow for the full range of content-area knowledge and skills to be demonstrated so that appropriate instructional decisions can be made on the basis of accurate interpretations.

The consequences of one's interpretations must also be considered in light of the purpose of an assessment. There might be positive (or negative) social consequences for students identified and labeled as gifted. For example, the Pygmalion effect and the idea of self-fulfilling prophecy are two common concepts that can result from academic labeling and can encourage students to live up to the label(s) they are given. In addition, teachers may develop expectations about their students based on firsthand or even secondhand knowledge that can cause their expectations to become a reality (see Principle 11). Regardless, considering the implications of interpretations (i.e., false positives and false negatives) is important because of the potential social consequences (e.g., identity issues) for learners.

\section{REFERENCES}

American Educational Research Association, American Psychological Association, \& National Council on Measurement in Education. (2014). Standards for educational and psychological testing. Washington, DC: American Educational Research Association.

American Psychological Association. (n.d.) Appropriate use of highstakes testing in our nation's schools. Retrieved from http:// www.apa.org/ pubs/info/ brochures/ testing.aspx

+Gates, J. (2010). Children with gifts and talents: Looking beyond traditional labels. Roeper Review, 32, 200- 206.

+Kane, M. T. (2013). Validating the interpretations and uses of test scores. J ournal of Educational Measurement, 50, 1- 73.

+ Makel, M. C., Matthew, M. S., Peters, S. P., Rambo-Hernandez, K., \&Plucker, J . A. (2016). How can so many students be invisible? Large percentages of American students perform above grade level. Baltimore, MD: J ohns Hopkins Institute for Education Policy. Retrieved from http:/ / education.jhu.edu/ edpolicy/ commentary/ PerformAboveGradeLevel
+Messick, S. (1980). Test validity and the ethics of assessment. American Psychologist, 35, 1012- 1027.

+Messick, S. (1998). Test validity: A matter of consequences. Social Indicators Research, 45, 35- 44.

+Messick, S. (2000). Consequences of test interpretation and use: The fusion of validity and values in psychological assessment. In R. D. Goffin \& E. Helmes (Eds.), Problems and solutions in human assessment (pp. 3- 20). Boston, MA: Kluwer.

+Mueller, C. E. (2009). Protective factors as barriers to depression in gifted and nongifted adolescents. Gifted Child Quarterly, 53, 3- 14.

+Peters, S., \& Matthews, M. (Eds.). (2016). Gifted education research in the field of economics [Special issue]. J ournal of Advanced Academics, 27(2).

Rist, R. C. (2011). On understanding the process of schooling: The contributions of labeling theory. In A. R. Sadovnik (Ed.), Sociology of education: A critical reader (2nd ed., pp. 71- 82). New York, NY: Routledge. 
